\title{
Androgen receptor moonlighting in the prostate cancer microenvironment
}

\author{
B Cioni', W Zwart',2 and A M Bergman ${ }^{1,3}$ \\ 1Division of Oncogenomics, The Netherlands Cancer Institute, Amsterdam, the Netherlands \\ 2Oncode Institute, The Netherlands Cancer Institute, Amsterdam, the Netherlands \\ 3Division of Medical Oncology, The Netherlands Cancer Institute, Amsterdam, the Netherlands \\ Correspondence should be addressed to A M Bergman: a.bergman@nki.nl
}

\begin{abstract}
Androgen receptor (AR) signaling is vital for the normal development of the prostate and is critically involved in prostate cancer (PCa). AR is not only found in epithelial prostate cells but is also expressed in various cells in the PCa-associated stroma, which constitute the tumor microenvironment (TME). In the TME, AR is expressed in fibroblasts, macrophages, lymphocytes and neutrophils. AR expression in the TME was shown to be decreased in higher-grade and metastatic PCa, suggesting that stromal AR plays a protective role against PCa progression. With that, the functionality of AR in stromal cells appears to deviate from the receptor's classical function as described in PCa cells. However, the biological action of AR in these cells and its effect on cancer progression remains to be fully understood. Here, we systematically review the pathological, genomic and biological literature on AR actions in various subsets of prostate stromal cells and aim to better understand the consequences of AR signaling in the TME in relation to PCa development and progression.
\end{abstract}

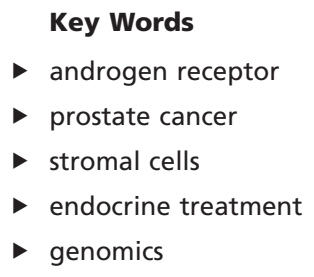

Endocrine-Related Cancer (2018) 25, R331-R349

\section{Prostate cancer}

Prostate cancer (PCa) is the second-most frequently diagnosed tumor type in men worldwide and the mostcommon male malignancy in developed countries (Torre et al. 2015). Annually, there are an estimated 1.1 million new prostate cancer cases worldwide and 300,000 cancer-related deaths (Ferlay et al. 2015). The main risk factors for PCa are ethnicity, family history and genetic predisposition. Moreover, prevalence increases with age, with the highest incidence between 70 and 75 years (Leitzmann \& Rohrmann 2012).

The majority of patients present with localized disease, in which the tumor is confined to the prostate. $\mathrm{PCa}$ is often detected after the development of lower urine tract complaints, while an increasing percentage of patients are being diagnosed before developing any symptoms as a result of prostate-specific antigen (PSA) testing (Leach et al. 2015). PSA is a serine protease, specifically secreted by epithelial prostate cells, which remains expressed in prostate cancer cells. Likelihood of recurrence after primary treatment is commonly estimated by the prognostic TNM classification of malignant tumors (tumor, lymph node involvement and distant metastasis) and the Gleason Score (GS); both prognostic scores based on histopathological features of the tumor.

Treatment options largely depend on stage and grade of the disease, as well as age, health condition and expected life span of the patient. For primary local treatment, a choice is made between radiotherapy and radical prostatectomy. Radical prostatectomy can be combined with extended pelvic nodal dissection (Briganti et al. 
2012), while radiotherapy can be combined with adjuvant androgen deprivation therapy (ADT) (Mottet et al. 2017). Both treatment modalities are considered equally effective in curing the disease (Kupelian et al. 2005, Peeters et al. 2006, Mottet et al. 2017). However, approximately 35\% of patients will develop a rise in PSA and a smaller proportion will develop metastatic disease (McLeod 2005). These patients cannot be cured, but the disease can be treated with ADT to which virtually all patients will respond.

\section{The prostate cancer microenvironment}

Stromal cells in an organ are all non-epithelial cells that jointly constitute the connective tissue. During normal tissue development, epithelial-stromal interactions are fundamental in order to maintain organ homeostasis. In prostate cancer, the tumor is surrounded by a large variety of stromal cells including resident fibroblasts, myofibroblasts, endothelial cells as well as innate and adoptive immune cells: the tumor microenvironment (TME). Apart from cells, tumors are influenced by soluble factors such as cytokines and other extracellular molecules that constitute the extracellular matrix (ECM). Components of the ECM are secreted by the tumor and the stromal cells, which can regulate tumor cell proliferation and migration (Joyce 2005). Moreover, cytokines released in the tumor microenvironment can control polarization of cells of the TME toward tumorsuppressive or tumor-promoting phenotypes (Corn 2012).

In multiple tumor types, including $\mathrm{PCa}$, tumorassociated stromal cells are highly plastic compared to the normal epithelium-associated stromal cells (Paland et al. 2009, Dulos et al. 2012, Lanciotti et al. 2014). During PCa development and progression, stromal cells show an altered phenotype, which leads to an increased ECM remodeling, angiogenesis, protease activity and immune cells infiltration (Rowley 1998). Tumor-associated stromal cells have been shown to undergo genetic alterations in the presence of a tumor, which might sustain the malignant phenotype (Hill et al. 2005).

Many studies have addressed the microenvironment as a prognostic factor in prostate cancer (Galon et al. 2012, Halama et al. 2012, Kadota et al. 2015, Fridman et al. 2017). Moreover, the TME gained a lot of interest over the last decades as a therapeutic target. Targeting various components of the TME might represent an alternative approach as compared to the classical therapies targeting cancer cells. This is an attractive concept, since (in contrast to tumor cells) stromal cells are normally regulated and do not show genetic instability. Based on this concept, new potential drugs targeting the cross-talk between cancer cells and stromal cells, such as Src kinase inhibitors, TGF- $\beta$ inhibitors and angiogenesis such as the vascular endothelial growth factor receptor inhibitors are now being tested in clinical trials (Bousquet et al. 2011, Araujo et al. 2012, Herbertz et al. 2015).

\section{AR expression in prostate cancer cells}

Nuclear receptors such as AR, but also estrogen receptor, glucocorticoid receptor and progesterone receptor are all expressed in prostate tissue and play a role in prostate cancer development and progression (Arora et al. 2013, Christoforou et al. 2014, Chen et al. 2017). AR is expressed in the epithelial cells of primary and metastatic PCa and regulates a variety of cellular functions (Heinlein \& Chang 2004). AR is a steroid hormone receptor located on chromosome Xq12 and a member of the nuclear receptor family (Rathkopf \& Scher 2013). Its transcript comprises of 8 exons and 3 functional domains: the N-terminal transactivation domain (NTD) in exon 1, the DNA-binding domain (DBD) in exon 2 and 3 and the C-terminal ligand-binding domain (LBD) in exon $5-8$. The AR transcript is translated into an $110 \mathrm{kDa}$ liganddependent transcription factor (van de Wetering et al. 2015) that plays a critical role in prostate cancer development and progression by regulating the transcription of genes involved in cell proliferation, migration, differentiation, cell cycling and apoptosis (Heinlein \& Chang 2004).

After entering the target cell, testosterone is converted into dihydrotestosterone (DHT) by 5 - $\alpha$-reductase, which has a high affinity for AR (Fig. 1). Upon DHT binding, AR dissociates from the heat-shock protein 90 complex (Hsp90) and undergoes intra-molecular conformational changes at the $\mathrm{N}$ - and C-terminal of the receptor (N/C interactions) (Schaufele et al. 2005). Consequently, the AR-DHT complex translocates into the nucleus where the receptor dimerizes (van Royen et al. 2012, Hu et al. 2017) and binds the DNA at androgen-responsive elements (ARE) of promoter and enhancer regions of various target genes (Tan et al. 2015).

AR/DNA binding is mediated by pioneering transcription factors (TFs) including forkhead box protein A1 (FOXA1), GATA-binding protein 2 (GATA2) and homebox protein 13 (HOXB13), that render ARE regions accessible for AR to bind (Stelloo et al. 2018). Subsequently, a variety of co-regulators are recruited to the complex that can either activate (coactivators, e.g. steroid receptor co-activator 1 (SRC-1), androgen receptor co-activator 70-alpha (ARA70-alpha)) (Foley \& Mitsiades 2016, Zhao et al. 2016) or repress (co-repressors, e.g. flightless I (FLI1), nuclear receptor co-repressor 1 (NCoR1)) (Hu et al. 2017) the expression of downstream-responsive genes. 




Figure 1

Schematic view of AR genomic function in prostate cancer (PCa) cells. In PCa cells, testosterone diffuses into the target cell, where it is converted in the cytosol into dihydrotestosterone (DHT) by $5 \alpha$-reductase. Subsequentially, DHT binds AR and induces the dissociation of Heat-Shock protein 90 (HSP90). DHT binding to AR promotes translocation into the nucleus, where AR dimerizes and binds the chromatin at androgen-responsive elements (AREs). AR binding at AREs is facilitated by other transcription factors (TFs) that regulate chromatin accessibility, such as FOXA1, GATA2 and HOXB13. Finally, chromatin-bound AR recruit's co-regulators that promote the interaction and activation of RNA polymerase II (RNA pollI) to regulate transcription of AR-responsive genes. Therapeutic interventions with anti-hormonal drugs are aimed to block the various steps of the AR genomic cascade: LHRH agonists and antagonists lower the levels of testosterone synthesized in the testicles; CYP17 inhibitors interfere with the biosynthesis of androgens in the gonads and adrenal glands; $5 \alpha$-reductase inhibitors blocks the testosterone-DHT transformation by inhibiting the $5 \alpha$-reductase enzyme; and antiandrogens bind AR and prevent the ligand-mediated AR translocation into the nucleus and binding to the DNA.

\section{AR as a therapeutic target}

Since AR signaling modulates the expression of critical genes involved in prostate cancer proliferation and migration, inhibiting AR action is the mainstay of treatment of metastasized disease and as an adjuvant treatment (Uhlman et al. 2009). Understanding the molecular mechanisms of AR function is essential to develop new drugs targeting any of the steps of the AR signaling cascade. Currently, multiple drugs targeting these steps in the AR pathway are introduced in clinical practice or are in clinical development (Table 1).

ADT is achieved by physical castration or luteinizing hormone-releasing hormone (LHRH) agonists and antagonists. The latter two interventions lower the level of the testosterone produced by the testicles by inhibiting the production of luteinizing hormone (LH) from the pituitary gland (Gomella 2009). Furthermore, anti-androgen treatment is commonly prescribed to PCa patients. Anti-androgens such as bicalutamide, flutamide and enzalutamide act by directly blocking AR function, while others such as the CYP17A1 inhibitors ketoconazole and abiraterone acetate inhibit extragonadal and intratumoral synthesis of androgens (Gomella et al. 2010).

Despite the very high response rate to AR targeting interventions in metastatic PCa patients, progression into metastasized castration-resistant prostate cancer (mCRPC) is inevitable, which is hallmarked by high morbidity and mortality (Elrefaey et al. 2014). In contrast to the previous believe that PCa developed a hormone-refractory stage (Chang 2007), we now know that prostate cancer cells develop a hypersensitivity to testosterone (Fujimoto et al. 2007), resulting in activation of the AR cascade at castrate levels of circulating hormones. In this mCRPC stage of the disease, AR remains expressed and a driver of disease progression (Eisenberger et al. 1998). Enzalutamide and abiraterone have shown clinical activity in MCRPC in combination with ADT (Efstathiou et al. 2012, Hussain et al. 2014), which confirms continued androgen dependence of $\mathrm{PCa}$ cells in this late stage of the disease.

Apart from further anti-hormonal interventions, taxane chemotherapy and radio nucleotides have also 
Table 1 Hormone therapy for prostate cancer patients: established drugs and clinical trials.

\begin{tabular}{l} 
Established therapies \\
\hline Androgen biosynthesis blockade \\
Ketoconazole (Uhlman et al. 2009) \\
Abiraterone (Valdman et al. 2010) \\
Androgen receptor blockade \\
Bicalutamide (van de Wetering et al. 2015) \\
Nilutamide (Vasu et al. 2003) \\
Flutamide (Visakorpi et al. 1995) \\
Enzalutamide (Vuk-Pavlovic et al. 2010) \\
LHRH agonists \\
Goserelin (Wang et al. 2001) \\
Histrelin (Whitacre et al. 1999) \\
Leuprolide (Wikstrom et al. 2009) \\
Triptorelin (Wunderlich et al. 2002) \\
LHRH antagonists \\
Degarelix (Yu et al. 2010) \\
Abarelix (Yu et al. 2013a) \\
AR NTD blockade \\
- \\
AR-targeted mustard conjugates \\
Estramustine phosphate (Yu et al. 2014) \\
Androgen therapy \\
-
\end{tabular}

shown activity in mCRPC in combination with ADT (Hotte \& Saad 2010).

The underlying mechanism of this high sensitivity to testosterone in mCRPC has been unraveled in recent years. Altered AR functions commonly occur, which are thought to develop during continued selection pressure induced by treatment (Taplin et al. 1995). The molecular mechanisms by which impaired AR activity is associated with PCa development and progression is complex and includes AR amplification, constitutive active AR splice variants, extra testicular testosterone synthesis (Taplin et al. 1995, Visakorpi et al. 1995, Koivisto et al. 1997, Marcelli et al. 2000, Hu et al. 2017), overexpression of AR cofactors (Buchanan et al. 2001, Heemers \& Tindall 2007), gain-offunction AR mutations in the LBD (Steinkamp et al. 2009) and intracrine androgen production (Locke et al. 2008).

Alternative spliced AR variants represent a key factor in resistance to hormonal intervention and are often found in mCRPC (Dehm \& Tindall 2011). One of the best characterized AR variant is AR-V7 (AR3), which is composed only of exon 1-3, which encode the NTD and DBD and is therefore capable of DNA binding (Hu et al. 2009). However, it is ligand independent and constitutively active. AR-V7 was significantly upregulated during PCa progression, and expression was correlated with disease recurrence after radical prostatectomy (Guo et al. 2009). Importantly, overexpression of AR-V7 in circulating tumor cells was associated with resistance to androgen ablation treatments in PCa patients (Antonarakis et al.

\begin{tabular}{l} 
In clinical trial \\
\hline TAK-700 (Vacchio et al. 2005) \\
Galeterone (van Royen et al. 2012) \\
ARN509 (Vignozzi et al. 2012) \\
ODM-201 (Viselli et al. 1995) \\
EPI-506 (NCT02606123) \\
Testosterone cypionate (Yu et al. 2013b)
\end{tabular}

2017b). Currently, occurrence of AR-V7 in circulating tumor cells is being validated as a predictive biomarker for anti-hormonal treatment insensitivity (Scher et al. 2016).

\section{AR expression in prostate cancer microenvironment}

There is a growing interest in the impact of stromal AR signaling on the development and progression of prostate cancer. While a large number of studies addressed the role of AR in epithelial cells, only a limited number of reports were focused on the role of AR in the stroma (Leach \& Buchanan 2017). However, it is well established that AR is expressed in stromal cells (Table 2) and stromal AR is lost during PCa progression (Singh et al. 2013, Cano et al. 2007, Singh et al. 2014). In various studies, decreased stromal AR expression was shown to be associated with biochemical relapse and poor prognosis (Henshall et al. 2001, Li et al. 2008, Wikstrom et al. 2009). These results suggest a protective role of stromal AR against PCa progression, which would be in contrast to the well-established role of AR in PCa cells. However, the role of AR in stromal cells of the TME remains largely unclear. Given the growing evidence for a key role of the TME in PCa development and progression, exploring the expression and function of $\mathrm{AR}$ in the tumor microenvironment is highly relevant.

The underlying mechanisms by which stromal AR expression is lost during prostate cancer progression remain largely unknown. However, some hypotheses 
Table 2 Functional and genomic features of AR signaling in the various cells of the prostate cancer microenvironment.

\begin{tabular}{|c|c|c|c|c|c|c|}
\hline Cell type & AR role & $\begin{array}{c}\text { Possible effect in } \\
\text { PCa }\end{array}$ & $\begin{array}{l}\text { DNA-binding } \\
\text { location }\end{array}$ & Function & $\begin{array}{l}\text { Pioneering } \\
\text { factors }\end{array}$ & References \\
\hline Prostate cells & $\begin{array}{l}\text { Maintenance of } \\
\text { prostate development } \\
\text { and morphogenesis. } \\
\text { Regulation of cell } \\
\text { growth and migration }\end{array}$ & $\begin{array}{l}\text { Increased } \\
\text { proliferation and } \\
\text { migration }\end{array}$ & $\begin{array}{l}\text { Distal } \\
\text { intergenic } \\
\text { and introns }\end{array}$ & Enhancer & $\begin{array}{l}\text { FOXA1, } \\
\text { GATA2, } \\
\text { HOXB13 }\end{array}$ & $\begin{array}{l}\text { Choudhry et al. } \\
\text { (2006), Chimal- } \\
\text { Ramirez et al. } \\
\text { (2013), Christoforou } \\
\text { et al. (2014), Chen } \\
\text { et al. (2017) }\end{array}$ \\
\hline Fibroblasts & $\begin{array}{l}\text { Regulation of cytokines } \\
\text { secretion and cross- } \\
\text { talk between stromal } \\
\text { and epithelial cells } \\
\text { (cytokine-cytokine } \\
\text { receptor interaction, } \\
\text { cell adhesion, } \\
\text { ECM-receptor } \\
\text { interaction) }\end{array}$ & $\begin{array}{l}\text { Up- or } \\
\text { downregulation } \\
\text { of tumor cell } \\
\text { growth and } \\
\text { migration }\end{array}$ & $\begin{array}{l}\text { Distal } \\
\text { intergenic } \\
\text { and introns }\end{array}$ & Enhancer & $\begin{array}{l}\text { c-Jun, c-Fos, } \\
\text { ATF, ZFX }\end{array}$ & $\begin{array}{l}\text { Lahita (1997), Gomez } \\
\text { et al. (2000), } \\
\text { Knutson \& Disis } \\
\text { (2005), Kupelian } \\
\text { et al. (2005), Ko } \\
\text { et al. (2008), Lai } \\
\text { et al. (2012a), } \\
\text { Kantoff et al. } \\
\text { (2010a), Keil et al. } \\
\text { (2014), Kissick et al. } \\
\text { (2014), Kumar et al. } \\
\text { (2016), Antonarakis } \\
\text { et al. (2017b) }\end{array}$ \\
\hline T lymphocytes & $\begin{array}{l}\text { Suppression T cells } \\
\text { proliferation. } \\
\text { Promotion of } \\
\text { differentiation of } \\
\text { FoxP3+ T cells (Tregs) } \\
\text { and Th2/Th1 T cells } \\
\text { ratio (via } \\
\text { downregulation of } \\
\text { IL-2, IFN- } \gamma \text {, and IL-12) }\end{array}$ & $\begin{array}{l}\text { Increased number } \\
\text { of 'pro-tumor' T } \\
\text { cells }\end{array}$ & - & - & - & $\begin{array}{l}\text { Miller \& Hunt (1996), } \\
\text { Marcelli et al. } \\
\text { (2000), Leav et al. } \\
\text { (2001), Liva \& } \\
\text { Voskuhl (2001), } \\
\text { Mantalaris et al. } \\
\text { (2001), Mercader } \\
\text { et al. (2001), } \\
\text { Messingham et al. } \\
\text { (2001), Ling et al. } \\
\text { (2002), Liu et al. } \\
\text { (2003, 2005), } \\
\text { McLeod (2005), } \\
\text { Miller et al. (2006), } \\
\text { Li et al. (2008), } \\
\text { Locke et al. (2008), } \\
\text { Madan et al. (2008), } \\
\text { Leitzmann \& } \\
\text { Rohrmann (2012), } \\
\text { Lessard et al. (2012), } \\
\text { Lin \& Wang (2016), } \\
\text { Liao et al. (2017) }\end{array}$ \\
\hline B lymphocytes & $\begin{array}{l}\text { Negative regulation of } \\
\text { B cells development } \\
\text { and differentiation } \\
\text { and antibodies } \\
\text { production }\end{array}$ & $\begin{array}{l}\text { Reduced humoral } \\
\text { immune response }\end{array}$ & - & - & - & $\begin{array}{l}\text { Mohler et al. (1996), } \\
\text { Nakajima et al. } \\
\text { (1996), Mueller \& } \\
\text { Fusenig (2004), Li } \\
\text { et al. (2008), Mottet } \\
\text { et al. (2017), Nash } \\
\text { et al. (2017) }\end{array}$ \\
\hline Neutrophils & $\begin{array}{l}\text { Positive regulation of } \\
\text { neutrophils } \\
\text { maturation, } \\
\text { proliferation and } \\
\text { inflammatory } \\
\text { cytokines production } \\
\text { (IL1- } \beta, \text { IL-6, TNF) }\end{array}$ & $\begin{array}{l}\text { Increased innate } \\
\text { immune reaction }\end{array}$ & - & - & - & $\begin{array}{l}\text { Nimmerjahn \& } \\
\text { Ravetch (2008), Niu } \\
\text { et al. (2008a) }\end{array}$ \\
\hline
\end{tabular}


Table 2 Continued.

\begin{tabular}{|c|c|c|}
\hline Cell type & AR role & $\begin{array}{c}\text { Possible effect in } \\
\text { PCa }\end{array}$ \\
\hline Macrophages & $\begin{array}{l}\text { Negative regulation of } \\
\text { TLR4, CCL2 and FcyR } \\
\text { expression. Increased } \\
\text { CCL4 production. Up- } \\
\text { and downregulation } \\
\text { of TNF }\end{array}$ & $\begin{array}{l}\text { Decreased immune } \\
\text { response and } \\
\text { phagocytosis. } \\
\text { Promotion of } \\
\text { tumorigenesis. } \\
\text { Up-or } \\
\text { downregulation } \\
\text { of EMT genes }\end{array}$ \\
\hline
\end{tabular}

Dendritic cells Negative regulation of inflammatory cytokines production (TNF, IL1- $\beta$, IL-6, etc.)

Endothelial cells mediated cell growth.
Decreased antigen presentation

Increased angiogenesis Induction of VEGFIncreased VCAM-1 expression. Increase TNF- $\alpha$-induced apoptosis
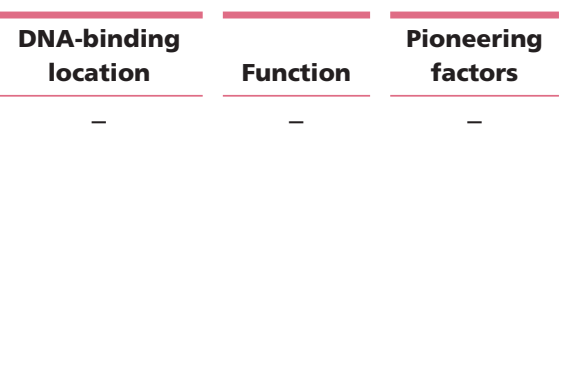

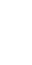

$-$

FOXO3

(n)

$-$

\begin{tabular}{l} 
References \\
\hline Olumi et al. (1999), \\
Roden et al. (2004), \\
Joyce (2005), \\
Peeters et al. (2006), \\
Rettew et al. (2008), \\
Gomella (2009), \\
Paland et al. (2009), \\
Nonomura et al. \\
(2011), Ricke et al. \\
(2012), Rathkopf \& \\
Scher (2013), O'Hara \\
\& Smith (2016), Pu \\
et al. (2016) \\
Rowley (1998), \\
Romagnani (1999), \\
Royuela et al. (2001) \\
\\
Schuurs \& Verheul \\
(1990), Sempowski \\
et al. (2000), \\
Schaufele et al. \\
(2005), Sfanos et al. \\
(2008), Singh et al. \\
(2013), Scher et al. \\
(2016)
\end{tabular}

Schuurs \& Verheul (1990), Sempowsk et al. (2000), Schaufele et al. (2005), Sfanos et al. singh et al. (2016) have been proposed, including increased epithelial AR expression during PCa development resulting in increased uptake of androgens by epithelial AR, which outcompetes stromal AR, possibly leading to reduced expression (Leach \& Buchanan 2017). Another option is that distinct inactivating AR mutations might occur in stroma. However, this remains an unexplored hypothesis as the only data available on AR-inactivating point mutations were originated from prostate cancer cells (Eisermann et al. 2013). Finally, epigenetic modifications have also been proposed, such as changes in methylation status of the AR promoter (Keil et al. 2014).

Interactions between stromal cells and PCa cells are frequently mediated by soluble factors, such as cytokines (Zhang \& Huang 2011). Testosterone and other sex hormones can modulate the adaptive and innate immune system; however, their effect might vary depending on the type of sex steroids. Indeed, estrogens are generally thought to promote pro-inflammatory cytokines production, whereas androgens are thought to suppress them (Ahmed 2010). The fact that males are in general more prone to infectious diseases and females are more prone to develop autoimmune diseases, supports this hypothesis (Schuurs \& Verheul 1990, Lahita 1997, Whitacre et al. 1999, Choudhry et al. 2006). However, relatively little is known about the mechanisms by which androgens affect the immune system.
Suppression of the pro-inflammatory signals by androgens might be mediated through reciprocal repression between AR and the NF- $\mathrm{B}$ signaling pathway, which is a well-known regulator of immune functions (De Bosscher et al. 2006, Kaarbo et al. 2007). Studies in rats showed that NF- $\mathrm{BB}$ was implicated in repression of the AR gene (Supakar et al. 1995). Moreover, NF-kB activation was shown to block the proliferation of androgen-dependent PCa cells, but not androgen-insensitive PCa cells (Nakajima et al. 1996). Also, in human benign prostatic hyperplasia cells, DHTinduced suppression of NF-кB-mediated inflammatory cytokine production was demonstrated (Vignozzi et al. 2012, Izumi et al. 2013). However, in LNCaP prostate cancer cells, no tethering of AR and NF- $\kappa \mathrm{B}$ was observed at the level of chromatin binding upon stimulation with androgens and $\mathrm{TNF} \alpha$, suggesting that they would not compete for the same genomic locations (Ko et al. 2008). Instead, redistribution of the AR pioneer factor FOXA1 was observed together with increased NF-кB-binding sites in the chromatin. This phenomenon was suggested to possibly 'mask' AR-binding sites due to redistribution of FOXA1 binding in the presence of inflammatory cytokines stimulation. Therefore, a potential negative regulation of AR function would be possible by activation of the NF- $\kappa B$ via inflammatory cytokines such as TNF $\alpha$.

In conclusion, AR expression in the PCa TME might profoundly affect the development of the disease. 
Therefore, the exact actions of AR in stromal cells warrant further characterization. Importantly, $\mathrm{AR}$ is expressed in various cells in the PCa stroma, which might have different kinetics and might affect PCa development in different ways (Fig. 2). We will discuss the available data on AR actions in the various cells of the TME below.

\section{The role of stromal AR signaling in PCa initiation}

AR signaling is vital for normal prostate development and critically involved in PCa initiation. However, the exact role of stromal AR in PCa initiation still needs to be elucidated. Stromal AR activity in tumor formation was initially explored by grafting AR-negative or AR-positive prostate tumor cells along with AR-negative or AR-positive urogenital sinus mesenchymal (UGM) cells in castrated mice, treated with or without androgen (Wang et al. 2001). Of mice grafted with AR-negative prostate cells and AR-positive UGM cells, 36\% showed tumor formation when treated with androgen compared to $0.5 \%$ in untreated mice. These results suggest the direct impact of stromal AR signaling on PCa initiation.

Other studies explored the role of stromal AR in the early stages of tumor transformation by grafting prostate cells with wild-type or testicular feminized mice mesenchyme (Ricke et al. 2012). When androgens were injected in mice grafted with prostate cells and wild-type mice mesenchyme, tumor development was observed. In contrast, tumor growth was significantly

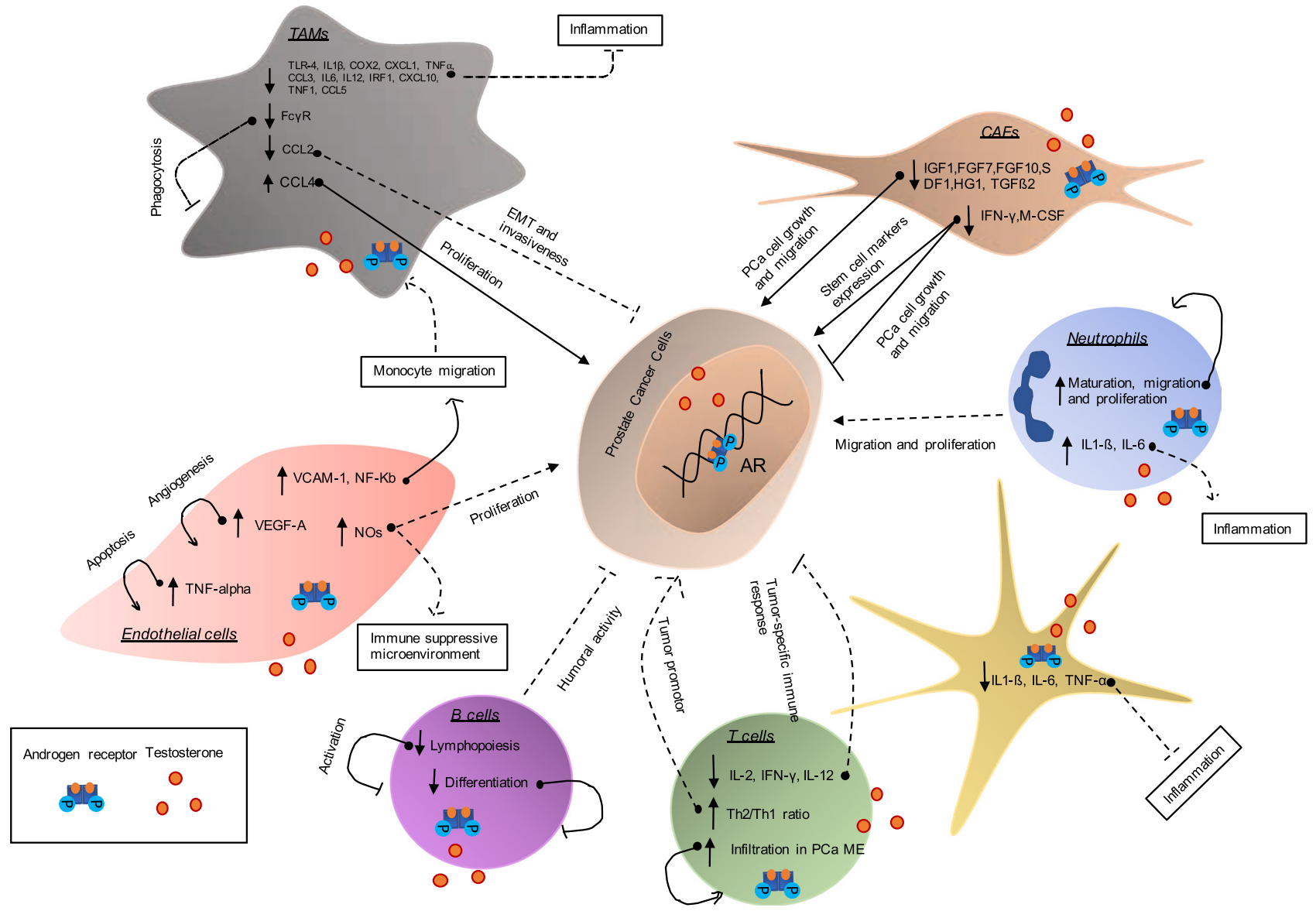

Figure 2

Potential role of androgen receptor (AR) signaling in the prostate cancer microenvironment. Schematic representation of AR signaling in prostate cancer cells and in the cells of the prostate tumor microenvironment (TME). In the TME non-immune cells, such as endothelial cells and cancer-associated fibroblasts (CAFs) and immune cells, such as neutrophils, dendritic cells (DCs), T cells, B cells and tumor-associated macrophages (TAMs) are found. As a result of AR actions, signals to the prostate cancer cells and to the microenvironment (boxed) can be activated. These signals might stimulate (arrow) or inhibit processes (truncated line). Solid lines indicate functions that have been established in prostate cancer, while segmented lines indicate putative actions based on known functions of cytokines. Signals that affect the TME cell itself, are indicated by a line looping back to the cell. In CAFs, opposite actions of AR signaling have been described (Lahita 1997, Koivisto et al. 1997, Kupelian et al. 2005, Koretzky 2010, Lai et al. 2012a, Kumar et al. 2016, Antonarakis et al. 2017a). 
impaired when testosterone was injected in mice grafted with prostate cancer cells and AR-negative testicular feminized mice mesenchyme, suggesting that stromal AR plays a key role in PCa development. Notably, the presence of AR in the epithelial cells did not seem to affect the development of PCa. These data are supported by a study showing that AR-positive stroma induced PCa development in grafted, AR-negative, benign prostatic hyperplasia (BPH)-1 cells (Wang et al. 2001). However, PCa development was delayed in mice lacking stromal AR (Niu et al. 2008a).

Cumulatively, these studies imply a role of stromal AR in initiation and early stages of PCa development. However, the role of stromal AR in later stages of PCa progression, including development of metastasis and mCRPC might be different as stromal AR is reduced or even lost at those stages of the disease (Singh et al. 2013, 2014).

\section{AR expression in prostate cancer-associated fibroblasts}

Fibroblasts represent one of the most abundant cell populations in the TME and one of their primary functions is to produce the structural and regulatory components of the ECM and a large variety of cytokines (Barron \& Rowley 2012). During prostate cancer development and progression, the stroma becomes reactive and undergoes structural and functional changes, which might affect the progression of the disease (Barron \& Rowley 2012). Relatively little is known about the exact mechanisms by which fibroblasts become activated into cancer-associated fibroblasts (CAFs); however, their role in modulation of tumorigenesis and progression is well documented (Olumi et al. 1999, Mueller \& Fusenig 2004). A recent study showed that CAFs in the TME of cutaneous squamous cell carcinoma are characterized by unique nuclear receptor (NR) expression profiles as compared to normal-associated fibroblasts, which might affect cancer cell invasiveness, proliferation and response to chemotherapy (Chan et al. 2017, Leach et al. 2017).

Recent studies described the genomic action of AR in immortalized stromal cells from BPH (PShTert-AR) and CAFs. Using chromatin immunoprecipitation, followed by massive parallel sequencing (ChIP-seq) in PShTert-AR cells, it was shown that AR binds the DNA upon testosterone stimulation via the activating protein-1 (AP-1) complex (Leach et al. 2017). However, this could not be confirmed in CAFs or primary embryonic prostate fibroblasts (EPFs) (Nash et al. 2017). In CAFs and EPFs, AR binding was reported proximal to the known AR-responsive genes ATAD2 and ARL8B, which was shared with PCa cells (Nash et al. 2017). However, the vast majority of AR chromatin-binding sites in CAFs were specific for this cell type and not shared with prostate cancer cells. In the same study, the zinc-finger protein X-linked (ZFX) was identified as a potential AR co-factor in EPFs but not in CAFs. This suggests that ZFX may function as an AR co-factor during embryonic development of the prostate, which disappears during differentiation. However, also in prostate tumors, ZFX was shown to be elevated and to drive cell proliferation and survival (Tricoli \& Bracken 1993, Jiang et al. 2012).

The consequences of AR signaling in CAFs for PCa development remains unestablished, since reports are not unequivocal. It was suggested that acceleration of human prostate cancer growth and migration was mediated by soluble factors secreted by CAFs (Gleave et al. 1991, 1992). Co-culture of CAFs in which AR was knocked down with PC3 prostate cancer cells resulted in decreased epithelial growth and diminished colony formation and invasion. This was mediated by reduced secretion of IGF1, FGF7, FGF10, SDF1, HGF and TGF $\beta 2$ (Yu et al. 2013a). In agreement with these results, conditioned medium of DHT-stimulated AR-positive WPMY-1 immortalized normal human prostate fibroblasts, significantly increased LnCap prostate cancer cell proliferation compared to non-stimulated fibroblasts (Tanner et al. 2011). Moreover, invasion of PCa cells co-cultured with WPMY-1 fibroblasts in which AR was knocked down, was significantly lower compared to co-culture with AR wild-type WPMY fibroblasts (Niu et al. 2008b). In contrast, it was reported that antisense oligonucleotide AR-silenced CAFs promoted $\mathrm{PCa}$ cells growth, colony formation and expression of stem cell markers by increased IFN- $\gamma$ and M-CSF expression (Liao et al. 2017). Furthermore, castrated mice co-grafted with patient-derived PCa tissue and PShTert-AR-positive myofibroblasts showed a significant increase of apoptotic PCa cells compared to PCa tissue co-grafted with AR-negative myofibroblasts, suggesting that loss of AR in myofibroblasts protects PCa cells from castration-induced apoptosis (Leach et al. 2015). There is no clear explanation why AR signaling in fibroblasts is both associated with increased and decreased PCa cell proliferation, migration and apoptosis. A potential explanation of these contrasting findings might be related to differences in the fibroblasts' origins (normal fibroblasts or CAFs) or variation in the duration of AR stimulation of the fibroblasts in the various studies. 
If $\mathrm{AR}$ actions in fibroblasts protects against prostate cancer development and metastatic potential, this would impact the way we look at anti-hormonal treatments. Although AR inhibition is the mainstay of metastasized disease treatment, this would also imply that this treatment has unwanted effects by disrupting the protective function of fibroblasts against disease progression.

\section{AR expression in adaptive immune cells}

The cell-mediated adaptive immune system largely consists of $\mathrm{B}$ and $\mathrm{T}$ lymphocytes. Various subsets of $\mathrm{T}$ cells have been described, most prominently CD8+ cells (commonly referred to as cytotoxic T cells) and CD4+ cells, also called T helper cells (Koretzky 2010). Moreover, various sub-populations of CD4+ T helper cells have been described in tumor inflammation, including the antitumor Th1 CD4+ cells, the pro-tumor Th2 CD4+ cells and regulatory T cells (Tregs) (Knutson \& Disis 2005).

The CD8+ and CD4+ subsets of T lymphocytes are present in the PCa-affected prostate gland; however, an unequivocal correlation between CD8+ and CD4+ $\mathrm{T}$ lymphocyte infiltration and prognosis has not been established yet. The number of infiltrating CD8+ and CD4+ cells was shown to be increased in cancer compared to benign tissue; however, no correlation with malignancy grade (GS) was observed (Valdman et al. 2010). Moreover, the numbers of immunosuppressive Tregs were found increased in the prostate and peripheral blood of PCa patients compared to healthy men (Miller et al. 2006, Sfanos et al. 2008). However, a clear relation between $\mathrm{T}$ cell infiltration in the PCa TME and clinical outcome is yet to be established, as both increased and decreased numbers of infiltrating $\mathrm{T}$ cells into the PCa TME were found to correlate with shorter PSA recurrence-free survival after radical prostatectomy (Flammiger et al. 2012).

Expression of classical intracellular AR (iAR) has been documented in $\mathrm{T}$ and $\mathrm{B}$ cells, while in $\mathrm{T}$ cells also a surface AR (sAR) was described (Viselli et al. 1995, Benten et al. 1999, 2002, 2004, Wunderlich et al. 2002). The functionality and significance of this sAR remains to be elucidated. A few studies have suggested that AR signaling in immune cells alters cytokine production in T cells (Bebo et al. 1999, Liva \& Voskuhl 2001), which may potentially affect prostate cancer development and progression (Izumi et al. 2014).

Thymic cells of AR knocked-out (ARKO) mice showed a lower expression of CD80/CD86 (also known as B7-2) activation marks compared to AR-proficient thymic cells (Lai et al. 2012a), which are believed to be required for proper antigen-mediated activation of $\mathrm{T}$ cells (Vasu et al. 2003). AR-mediated activation of thymic cells was confirmed in another study where AR was shown to upregulate CD80 and CD86 by direct promoter binding (Lai et al. 2013). However, in thymic cells of ARKO mice, an increased expression of IL-7 and CCL21 was shown, while TGF $\beta 1$ and IL-6 expression was decreased. IL-7 and CCL21 were reported to promote thymopoiesis (Liu et al. 2005), while TGF $\beta 1$ and IL-6 were suggested to inhibit it (Sempowski et al. 2000). This would be in contrast to the suggested AR-mediated activation of thymic cells based on CD80/CD86 expression. However, reports on the role of CD80/CD86 in T cell activation are not unequivocal, since another study reported that double CD80/CD86-KO mice showed increased numbers of mature CD4 and CD8 splenic T cells (Vacchio et al. 2005), suggesting that increased CD80/CD86-mediated activation of $\mathrm{T}$ cells might negatively regulate the maturation and differentiation of $\mathrm{T}$ cells.

In mature $\mathrm{T}$ cells, AR signaling was shown to have a dual role. AR activation suppresses $\mathrm{T}$ cell proliferation in mice and in vitro (Roden et al. 2004), and it modulated the balance between CD4+ Th1 and Th2 (T helper cells) response, skewing the differentiation toward the Th2 phenotype in peripheral blood of ADT-treated PCa patients (Kissick et al. 2014). A possible explanation for AR-mediated Th2 polarization is the suppression of IL-2, IFN- $\gamma$ and IL-12 expression in T cells (Messingham et al. 2001, Kissick et al. 2014), which are known to be key signals for the Th1 polarization (Romagnani 1999, Bettelli \& Kuchroo 2005). In CD4+ T cells, AR was found to bind an intronic region of the protein tyrosine phosphatase non-receptor type 1 (Ptpn1) locus (Lessard et al. 2012). Moreover, ptpn1 expression was decreased in CD4+ cells isolated from patients undergoing ADT (Kissick et al. 2014). In the same study, upregulation of Ptpn1 in human and mouse androgen-treated CD4+ T cells was associated with IL-12 inhibition, which prevented STAT4 phosphorylation and ultimately blocked Th1 polarization, potentially contributing to a sustained tumor-specific immune response. The AR-mediated Th1 to Th2 T cell switch might support PCa development and progression as Th2 $\mathrm{T}$ cells have been widely described to favor a protumor and immunosuppressive microenvironment, through cytokines that support the presence of myeloidderived suppressor cells (MDSCs) and tumor-associated macrophages (TAMs) (Grivennikov et al. 2010, ChimalRamirez et al. 2013). 
AR is also expressed in immature murine B cells (Mantalaris et al. 2001). In vitro and in vivo studies showed that blockade of AR signaling enhanced B cell lymphopoiesis, demonstrating that B cell development is negatively regulated by androgens and AR signaling (Smithson et al. 1998, Ellis et al. 2001, Altuwaijri et al. 2009). These data suggest that hormonal therapy increases the generation of young B cells; however, it is not clear how this might affect PCa.

AR signaling seems to affect maturation of $\mathrm{T}$ and $\mathrm{B}$ cells. However, there is limited data on the relevance of AR signaling in T and B cells for prostate cancer development. In $\mathrm{T}$ cells, AR signaling regulates the expression of various cytokines that might affect PCa development.

\section{AR expression in innate immune cells}

Cells of the innate immune system (e.g. macrophages, dendritic cells (DCs), MDSCs and neutrophils) promote phagocytosis and lysis of bacteria and virus-infected cells and are critically involved in the immunological response to cancer development and progression. Within the same subset of innate immune cells, various phenotypes may be present that affect $\mathrm{PCa}$ development and progression. The effects of androgens on innate immune cells functions are largely unexplored; however, several androgen-driven mechanisms of action have been proposed, as further discussed below.

\section{Neutrophils and polymorphonuclear cells}

Neutrophils or polymorphonuclear neutrophils (PMNs) kill tumor cells by either phagocytosis or releasing toxic oxygen-free radicals (Elrefaey et al. 2014). It is suggested that neutrophils can be present in the TME as N1-like neutrophils (anti-tumorigenic) or $\mathrm{N}_{2}$-like neutrophils (pro-tumorigenic), and therefore, contribute to both suppression and promotion of the tumor (de Oliveira et al. 2016). Although a clear distinction between these two neutrophils phenotypes in PCa and correlation with survival is lacking, an elevated neutrophils-tolymphocytes ratio in the peripheral blood is associated with lower response rates to abiraterone and docetaxel treatment in mCRPC patients (Templeton et al. 2014, Cao et al. 2016, Gu et al. 2016).

AR expression is not established in human neutrophils; however, AR was strongly expressed in mouse neutrophils (Mantalaris et al. 2001). A study in ARKO mice reported significant reduction of neutrophil proliferation and maturation (Chuang et al. 2009), possibly via reduced phosphorylation of STAT3 and ERK, which are essential for myeloid cells differentiation. As a consequence, production of chemokines and cytokines such as IL1- $\beta$, IL- 6 and TNF- $\alpha$ was also reduced in granulocytes of ARKO mice. This would suggest that AR in neutrophils decreases the number of neutrophils and supports their phenotype. However, in the same study, ADT did not significantly affect peripheral blood neutrophil counts in patients. Although an impact of AR signaling in neutrophils on PCa development and progression has not been established, an AR mediated inhibition of neutrophil maturation may be associated with a better clinical outcome as high neutrophil-tolymphocyte ratio in prostate cancer patients is associated with biochemical recurrence and shorter overall survival (OS) in several clinical studies (Templeton et al. 2014, Cao et al. 2016, Gu et al. 2016).

\section{Macrophages}

Macrophages are found in most organs of the human body and are derived from circulating monocytes, which differentiate into macrophages when entering the tissue (Italiani \& Boraschi 2014). Unlike neutrophils, macrophages are capable of repeated phagocytosis and can secrete inflammatory cytokines (Elrefaey et al. 2014). However, similar to neutrophils, phenotypic subsets occur with contrasting actions on tumor cells. M1-like and M2-like macrophages are so-called pro-inflammatory macrophages and TAMs, respectively (Elrefaey et al. 2014). The number of infiltrating TAMs in the prostate cancer microenvironment was predictive for disease progression after hormonal therapy (Nonomura et al. 2011). Moreover, increased numbers of cancer-associated M2 macrophages was associated with extra-capsular tumor extension (Lanciotti et al. 2014).

In general, androgens are thought to inhibit macrophage function in vivo and in vitro (Miller \& Hunt 1996). For instance, AR knockdown suppresses migration of the macrophage cell line THP-1 (Huang et al. 2014), suggesting that AR in macrophages might support the migration ability of these cells. However, AR knockdown in THP-1 cells also induces expression of CCL2, which promotes EMT and enhances invasiveness of malignant cells (Izumi \& Chang 2013, Izumi et al. 2013).

Moreover, androgen stimulation of murine macrophages reduced the expression of Toll-like receptor 4 (TLR4) (Rettew et al. 2008). Downregulation of TLR4 expression alters the MyD88-dependent and-independent pathways, which leads to decreased expression of various 
pro-inflammatory molecules such as IL1- $\beta$, COX2, CXCL1, TNF- $\alpha$, CCL3, IL-6, IL-12, IRF1, CXCL10, TNF1 and CCL5 (Bjorkbacka et al. 2004). Furthermore, expression of receptors for the Fc region of IgG $(\mathrm{Fc} \gamma \mathrm{R})$ on macrophages was reduced in guinea pig models after testosterone stimulation (Gomez et al. 2000). As Fc $\gamma \mathrm{R}$ expression in innate cells is crucial for phagocytosis and the release of inflammatory mediators (Nimmerjahn \& Ravetch 2008), these data suggest that AR activation in macrophages decreases antibody-mediated phagocytosis via reduction of Fc $\gamma \mathrm{R}$ expression.

Interestingly, co-culture of normal prostate epithelial RWPE-1 cells with the THP-1 macrophage cell line induced prostate tumorigenesis in 3D cultures (Fang et al. 2013). In the presence of THP-1 macrophages, RWPE- 1 cells differentiated into a disorganized aggregate structure, suggesting that soluble factors secreted by THP-1 cells interfere with the normal development of well-organized spheroids of glandular prostate epithelial cells also called prostaspheres. These observations were confirmed in vivo as all mice injected with both RWPE and THP-1 cells developed tumors, while none of the mice injected with either RWPE or THP-1 alone developed tumors. In the same study, the expression of several EMT-associated genes in RWPE-1 cells was increased after co-culture with THP-1 macrophages, including CCL4. CCL4 was previously identified as an AR-responsive gene and proposed as a main driver of tumorigenesis and EMT (Lai et al. 2012b). In this study, antibody-based blocking of CCL4 in the co-culture experiments showed significant reduction of THP-1-mediated cell migration and EMT-related gene expression in RWPE-1 cells. AR expression in THP-1 macrophages was proposed to be responsible for the cross-talk between THP-1 cells and RWPE- 1 cells as knocking down AR in THP- 1 cells reduced CCL4 expression. This key role of AR-mediated CCL4 expression was confirmed in vivo, since macrophage-AR knockout (M-ARKO)/PTEN+/- mice showed decreased CCL4 levels and reduced preneoplastic prostatic intraepithelial neoplasia formation when compared to tumors from $\mathrm{PTEN}^{+/-}$mice. Although these findings demonstrate a role of AR in macrophage-associated inflammatory response, the underlying mechanisms remains unclear.

In conclusion, these results suggest that AR signaling affects multiple functions of macrophages, including migration, cytokine production and phagocytosis. All of these might affect prostate cancer development. Moreover, macrophages might increase prostate cancer cell EMT mediated through AR-regulated CCL4 expression.

\section{Dendritic cells}

Dendritic cells (DC) share many features with macrophages and play an important role in $\mathrm{T}$ cell activation and assist their regulation into Th1 and Th2 differentiation.

Very little is known about the role of AR in DCs. DCs do express AR and androgens decrease production of the inflammatory cytokines IL1- $\beta$, IL- 6 and TNF- $\alpha$ (Corrales et al. 2006). In agreement, DHT-stimulated bone marrow-derived dendritic cells showed decreased IL-6, which is fundamental for the maturation of DCs, while production of anti-inflammatory cytokines IL-4 and IL-10 was increased upon DHT treatment (Zhao et al. 2014). However, the genomic mechanisms of AR signaling in DCs as well as the possible effect thereof on PCa development and progression are yet to be explored. As a result of AR-mediated impairment of DCs maturation, activation of CD8+ T cells may be suppressed, preventing effective tumor killing. Therefore, we speculate that AR function in DCs might promote the progression of PCa via preventing CD8+ T cell tumor-specific activation.

\section{AR expression in endothelial cells}

Endothelial cells are key components of blood vessels. Abnormalities in growth, function and organization of endothelial cells often occur in concert with the development and progression of atherosclerosis and cancer. Very little is known about the effects of androgens on endothelial cells. Human umbilical vein EA.hy926 endothelial cells have a functional AR, and AR stimulation increases TNF- $\alpha$-induced apoptosis of these cells (Ling et al. 2002, Liu et al. 2003). In contrast, another study reported that AR promotes endothelial cell proliferation through AR/VEGF-A/cyclin-Amediated mechanisms (Cai et al. 2011). Given the opposing conclusions of studies exploring the effects of AR signaling in endothelial cells on proliferation and survival, a clear role of AR in angiogenesis and consequently $\mathrm{PCa}$ development remains elusive. AR stimulation induced vascular cell adhesion molecule 1 (VCAM-1) expression in endothelial cells, which led to increased monocyte binding to the endothelium, promoting monocyte migration into the TME (Death et al. 2004). Testosterone was shown to rapidly induce nitric oxide (NO) production in human aortic endothelial cells (HAECs) (Yu et al. 2010), which is known to support an immune suppressive microenvironment, promote cancer cell growth and prevent apoptosis (Grimm et al. 2013). 
Altogether, these data would suggest a potential role of endothelial AR in PCa development and progression, mediated by increased angiogenesis and accelerated recruitment of immune cells into the PCa microenvironment.

\section{Other steroid hormone receptors in the PCa microenvironment}

Expression of other steroid hormone receptors (SHR) such as estrogen receptor (ER), glucocorticoid receptor (GR) and progesterone receptor (PR) has been described in the PCa stroma. However, their role in specific stromal cell types is largely unknown. Both ER $\alpha$ and ER $\beta$ are expressed in the PCa-associated stroma (Gangkak et al. 2017). While ER $\alpha$ is predominantly found in the stromal compartment, ER $\beta$ is mainly expressed in the basal-epithelial cells (Leav et al. 2001, Royuela et al. 2001, Gangkak et al. 2017). One study showed that increased expression of ER $\alpha$ but not ER $\beta$ in the stroma was associated with advanced disease (Daniels et al. 2014). However, another study showed that PCa patients with ER $\alpha$-positive stromal staining had a significantly lower risk of biochemical recurrence after local therapy (Slavin et al. 2014). In the same study, in vitro experiments revealed that stromal ER $\alpha$ reduced PCa cell invasion possibly by downregulating matrix metalloproteinase 3 (MMP3) expression and increased expression of thrombospondin 2 (Thbs2).

GR is expressed in the stroma of both human BPH and PCa (Mohler et al. 1996). Glucocorticoids play a key role in immune cells as they are potent anti-inflammatory agents that act via transrepression of GR through tethering to various TFs, including AP-1 and NF-кB (Lin \& Wang 2016). Therefore, targeting GR in PCa patients might potentiate the efficacy of current therapies.

$\mathrm{PR}$ is also expressed in the stromal compartment of $\mathrm{PCa}$, and levels were lower compared to normal prostate stroma. Conditioned medium from PR-positive stromal cells inhibits prostate cancer cell migration and invasion, possibly via downregulation of CXCL12 and IL-6 production (Yu et al. 2014). Moreover, PR was shown to inhibit prostate stromal cell proliferation (Yu et al. 2013b).

These data suggest that activity of SHRs in the stromal compartment may affect PCa development and progression. However, there are limited data on their actions and no data on interactions between the various SHRs. More studies are needed to explore the exact role of SHRs in PCa cells and PCa-associated stroma.

\section{New prospective for hormone therapy and immunotherapy in $\mathrm{PCa}$}

Immunotherapy was chosen by Science's editors as the 'breakthrough of the year 2013' and represents a new potential weapon for fighting cancer by exploiting the immune system. Although effective in melanoma, non-small-cell lung cancer and bladder cancer, thus far immunotherapy has shown limited efficacy in PCa patients (Higano et al. 2009, Kantoff et al. 2010b, Topalian et al. 2012, Beer et al. 2017).

One potential explanation for this lack of efficacy is the low mutational load of PCa cells, limiting the repertoire of neo-antigens that are required for recognition of cancer cells by activated $\mathrm{T}$ cells (Alexandrov et al. 2013). Another potential explanation for the low success rate of immunotherapy in $\mathrm{PCa}$ is the presence of an immunosuppressive TME. CD25+ and FoxP3+ Tregs as well as PD1+ exhausted T cells were found to surround prostate cancer islets in untreated PCa patients (Ebelt et al. 2009). Moreover, levels of circulating immune-suppressive CD14+HLA-DR ${ }^{\text {low/- }}$ MDSCs were significantly increased in the blood of PCa patients, compared to healthy controls (Vuk-Pavlovic et al. 2010). Importantly, MDSCs become more immune suppressive in the tumor and can differentiate into TAMs, supporting tumor growth (Kumar et al. 2016).

Non-immune stromal cells might also contribute to immune suppression by releasing specific stromal factors. Myofibroblasts present in the PCa microenvironment were shown to release CCL2, IL-6 and TGF- $\beta$, promoting differentiation of DCs into tumor-associated DCs (TADCs) via increased expression of IL-10 and PD-L1. This reduced the cross-presentation of tumor antigens to CD8+ T cells and TADCs-mediated T cell proliferation (Spary et al. 2014).

The effect of ADT therapy on the immune system remains elusive. ADT treatment is reported to increase the level of $\mathrm{T}$ cells in peripheral blood of mice (Roden et al. 2004) and in human PCa tissue (Mercader et al. 2001, Gannon et al. 2009). However, recent studies demonstrated that ADT suppresses T cell differentiation and activation, which hampers the efficacy of immunotherapy (Lai et al. 2012a, Pu et al. 2016). Moreover, others demonstrated that ADT also promotes the expansion of immunosuppressive Tregs and TAMs (Bao et al. 2012, Escamilla et al. 2015), which counteract the accumulation of tumor-infiltrating lymphocytes observed upon ADT treatment.

Mouse prostate tumor (Myc-Cap)-bearing mice treated with CpG, a TLR9 agonist which activates 
DCs, showed a suppressed tumor-specific CD8+ T cells immune response upon treatment with the AR antagonist flutamide. More specifically, AR antagonist treatment was shown to suppress $\mathrm{T}$ cells priming ( $\mathrm{Pu}$ et al. 2016). These data suggest that AR inhibition impairs the efficacy of immune checkpoint inhibitors treatment of PCa patients. Furthermore, it was recently reported that ADT decreases the expression of the immune checkpoint marker, programmed death ligand 1 (PD-L1) possibly limiting the effect the anti-PD-L1 immune checkpoint therapy (Calagua et al. 2017).

Recent advances of vaccination therapy in $\mathrm{PCa}$ treatment led to the development of sipuleucel-T, a therapeutic vaccine shown to prolong OS of mCRPC patients treated with ADT (Kantoff et al. 2010a). Clinical outcome of sipuleucel-T treatment was not affected by ADT, as no difference in efficacy was found between patients treated with ADT compared to patients that were treated with ADT after completion of sipuleucel-T treatment (Antonarakis et al. 2017a). However, a small study in sipuleucel-T-treated patients suggested that vaccination followed by treatment with the anti-androgen nilutamide improved survival, as compared with patients who first received anti-androgen therapy and then vaccine (Madan et al. 2008).

All together, these data suggest that AR blockade impairs the tumor-specific immune response. Additional studies are required to optimize combination strategies for the treatment of PCa patients.

\section{Conclusions}

In this review, we explored the role of $\mathrm{AR}$ in various cells of the prostate cancer microenvironment and its potential effect on the development of prostate cancer. Understanding the functional mechanisms of AR expression in the stroma is relevant, since unwanted effects of hormone therapy can be expected as AR in the epithelial and stromal compartments controls different signaling pathways. However, these putative opposing effects have not been explored. Cell-specific AR targeting has been described in mouse studies using the Cre/Lox system (De Gendt \& Verhoeven 2012, O'Hara \& Smith 2016), but not in the context of cancer. Opposing effects on prostate cancer growth of stromal and epithelial AR signaling might be targeted by endocrine agents with cell type-selective actions. Drugs that would specifically target AR in the stroma or in the cancer cells might have an enhanced anti-cancer activity with less side effects, either alone or in combination with ADT. Another approach would be to target cell-specific genes downstream of AR in prostate cancer cells. For instance, hormonal therapy could be combined with agents blocking the AR-mediated cytokine release or the receptors thereof, which support PCa development and progression.

\section{Declaration of interest}

The authors declare that there is no conflict of interest that could be perceived as prejudicing the impartiality of this review.

\section{Funding}

This work was supported by the Marie Curie Initial Training Network TIMCC (FP7-PEOPLE-2012-ITN, grant number: 317445).

\section{Acknowledgment}

The authors thank Suzan Stelloo and Dr Stefan Prekovic who contributed to this work with stimulating discussions.

\section{References}

Ahmed A, Karpuzoglu E \& Khan D 2010 Effects of sex steroids on innate and adaptive immunity. In Sex Hormones and Immunity to Infection, Chapter 2. New York, NY, USA: Springer.

Alexandrov LB, Nik-Zainal S, Wedge DC, Aparicio SA, Behjati S, Biankin AV, Bignell GR, Bolli N, Borg A, Borresen-Dale AL, et al. 2013 Signatures of mutational processes in human cancer. Nature $\mathbf{5 0 0}$ 415-421. (https://doi.org/10.1038/nature12477)

Altuwaijri S, Chuang KH, Lai KP, Lai JJ, Lin HY, Young FM, Bottaro A, Tsai MY, Zeng WP, Chang HC, et al. 2009 Susceptibility to autoimmunity and B cell resistance to apoptosis in mice lacking androgen receptor in B cells. Molecular Endocrinology 23 444-453. (https://doi.org/10.1210/me.2008-0106)

Antonarakis ES, Kibel AS, Yu EY, Karsh LI, Elfiky A, Shore ND, Vogelzang NJ, Corman JM, Millard FE, Maher JC, et al. 2017a Sequencing of sipuleucel-T and androgen deprivation therapy in men with hormone-sensitive biochemically recurrent prostate cancer: a phase II randomized trial. Clinical Cancer Research 23 2451-2459. (https://doi.org/10.1158/1078-0432.CCR-16-1780)

Antonarakis ES, Lu C, Luber B, Wang H, Chen Y, Zhu Y, Silberstein JL, Taylor MN, Maughan BL, Denmeade SR, et al. 2017b Clinical significance of androgen receptor splice variant-7 mRNA detection in circulating tumor cells of men with metastatic castration-resistant prostate cancer treated with first- and second-line abiraterone and enzalutamide. Journal of Clinical Oncology 35 2149-2156. (https://doi. org/10.1200/JCO.2016.70.1961)

Araujo JC, Mathew P, Armstrong AJ, Braud EL, Posadas E, Lonberg M, Gallick GE, Trudel GC, Paliwal P, Agrawal S, et al. 2012 Dasatinib combined with docetaxel for castration-resistant prostate cancer: results from a phase 1-2 study. Cancer 118 63-71. (https://doi. org/10.1002/cncr.26204)

Arora VK, Schenkein E, Murali R, Subudhi SK, Wongvipat J, Balbas MD, Shah N, Cai L, Efstathiou E, Logothetis C, et al. 2013 Glucocorticoid receptor confers resistance to antiandrogens by bypassing androgen receptor blockade. Cell 155 1309-1322. (https://doi.org/10.1016/j. cell.2013.11.012)

Bao SH, Shuai W, Tong J, Wang L, Chen P \& Sun J 2012 Increased expression of Toll-like receptor 3 in decidual natural killer cells of 
patients with unexplained recurrent spontaneous miscarriage. European Journal of Obstetrics and Gynecology and Reproductive Biology 165 326-330. (https://doi.org/10.1016/j.ejogrb.2012.08.005)

Barron DA \& Rowley DR 2012 The reactive stroma microenvironment and prostate cancer progression. Endocrine-Related Cancer 19 R187-R204. (https://doi.org/10.1530/ERC-12-0085)

Bebo BF Jr, Schuster JC, Vandenbark AA \& Offner H 1999 Androgens alter the cytokine profile and reduce encephalitogenicity of myelinreactive T cells. Journal of Immunology 162 35-40.

Beer TM, Kwon ED, Drake CG, Fizazi K, Logothetis C, Gravis G, Ganju V, Polikoff J, Saad F, Humanski P, et al. 2017 Randomized, double-blind, phase III trial of ipilimumab versus placebo in asymptomatic or minimally symptomatic patients with metastatic chemotherapy-naive castration-resistant prostate cancer. Journal of Clinical Oncology 35 40-47. (https://doi.org/10.1200/ JCO.2016.69.1584)

Benten WP, Lieberherr M, Giese G, Wrehlke C, Stamm O, Sekeris CE, Mossmann H \& Wunderlich F 1999 Functional testosterone receptors in plasma membranes of T cells. FASEB Journal 13 123-133. (https:// doi.org/10.1096/fasebj.13.1.123)

Benten WP, Stephan C \& Wunderlich F 2002 B cells express intracellular but not surface receptors for testosterone and estradiol. Steroids $\mathbf{6 7}$ 647-654. (https://doi.org/10.1016/S0039-128X(02)00013-2)

Benten WP, Guo Z, Krucken J \& Wunderlich F 2004 Rapid effects of androgens in macrophages. Steroids 69 585-590. (https://doi. org/10.1016/j.steroids.2004.05.007)

Bettelli E \& Kuchroo VK 2005 IL-12- and IL-23-induced T helper cell subsets: birds of the same feather flock together. Journal of Experimental Medicine 201 169-171. (https://doi.org/10.1084/ jem.20042279)

Bjorkbacka H, Fitzgerald KA, Huet F, Li X, Gregory JA, Lee MA, Ordija CM, Dowley NE, Golenbock DT \& Freeman MW 2004 The induction of macrophage gene expression by LPS predominantly utilizes Myd88-independent signaling cascades. Physiological Genomics 19 319-330. (https://doi.org/10.1152/ physiolgenomics.00128.2004)

Bousquet G, Alexandre J, Le Tourneau C, Goldwasser F, Faivre S, de Mont-Serrat H, Kaiser R, Misset JL \& Raymond E 2011 Phase I study of BIBF 1120 with docetaxel and prednisone in metastatic chemonaive hormone-refractory prostate cancer patients. British Journal of Cancer 105 1640-1645. (https://doi.org/10.1038/bjc.2011.440)

Briganti A, Larcher A, Abdollah F, Capitanio U, Gallina A, Suardi N, Bianchi M, Sun M, Freschi M, Salonia A, et al. 2012 Updated nomogram predicting lymph node invasion in patients with prostate cancer undergoing extended pelvic lymph node dissection: the essential importance of percentage of positive cores. European Urology 61 480-487. (https://doi.org/10.1016/j. eururo.2011.10.044)

Buchanan G, Irvine RA, Coetzee GA \& Tilley WD 2001 Contribution of the androgen receptor to prostate cancer predisposition and progression. Cancer and Metastasis Reviews 20 207-223. (https://doi. org/10.1023/A:1015531326689)

Cai J, Hong Y, Weng C, Tan C, Imperato-McGinley J \& Zhu YS 2011 Androgen stimulates endothelial cell proliferation via an androgen receptor/VEGF/cyclin A-mediated mechanism. American Journal of Physiology: Heart and Circulatory Physiology 300 H1210-H1221. (https://doi.org/10.1152/ajpheart.01210.2010)

Calagua C, Russo J, Sun Y, Schaefer R, Lis R, Zhang Z, Mahoney K, Bubley GJ, Loda M, Taplin ME, et al. 2017 Expression of PD-L1 in hormone-naive and treated prostate cancer patients receiving neoadjuvant abiraterone acetate plus prednisone and leuprolide. Clinical Cancer Research 23 6812-6822. (https://doi. org/10.1158/1078-0432.CCR-17-0807)

Cano P, Godoy A, Escamilla R, Dhir R \& Onate SA 2007 Stromalepithelial cell interactions and androgen receptor-coregulator recruitment is altered in the tissue microenvironment of prostate cancer. Cancer Research 67 511-519. (https://doi.org/10.1158/00085472.CAN-06-1478)

Cao J, Zhu X, Zhao X, Li XF \& Xu R 2016 Neutrophil-to-lymphocyte ratio predicts PSA response and prognosis in prostate cancer: a systematic review and meta-analysis. PLOS ONE 11 e0158770. (https://doi.org/10.1371/journal.pone.0158770)

Chan JSK, Sng MK, Teo ZQ, Chong HC, Twang JS \& Tan NS 2017 Targeting nuclear receptors in cancer-associated fibroblasts as concurrent therapy to inhibit development of chemoresistant tumors. Oncogene 37 160-173. (https://doi.org/10.1038/ onc.2017.319)

Chang SS 2007 Treatment options for hormone-refractory prostate cancer. Reviews in Urology 9 (Supplement 2) S13-S18.

Chen R, Yu Y \& Dong X 2017 Progesterone receptor in the prostate: a potential suppressor for benign prostatic hyperplasia and prostate cancer. Journal of Steroid Biochemistry and Molecular Biology 166 91-96. (https://doi.org/10.1016/j.jsbmb.2016.04.008)

Chimal-Ramirez GK, Espinoza-Sanchez NA \& Fuentes-Panana EM 2013 Protumor activities of the immune response: insights in the mechanisms of immunological shift, oncotraining, and oncopromotion. Journal of Oncology 2013 835956. (https://doi. org/10.1155/2013/835956)

Choudhry MA, Bland KI \& Chaudry IH 2006 Gender and susceptibility to sepsis following trauma. Endocrine, Metabolic and Immune Disorders: Drug Targets 6 127-135. (https://doi. org/10.2174/187153006777442422)

Christoforou P, Christopoulos PF \& Koutsilieris M 2014 The role of estrogen receptor beta in prostate cancer. Molecular Medicine 20 427-434. (https://doi.org/10.2119/molmed.2014.00105)

Chuang KH, Altuwaijri S, Li G, Lai JJ, Chu CY, Lai KP, Lin HY, Hsu JW, Keng P, Wu MC, et al. 2009 Neutropenia with impaired host defense against microbial infection in mice lacking androgen receptor. Journal of Experimental Medicine 206 1181-1199. (https://doi. org/10.1084/jem.20082521)

Corn PG 2012 The tumor microenvironment in prostate cancer: elucidating molecular pathways for therapy development. Cancer Management and Research 4 183-193. (https://doi.org/10.2147/CMAR. S32839)

Corrales JJ, Almeida M, Burgo R, Mories MT, Miralles JM \& Orfao A 2006 Androgen-replacement therapy depresses the ex vivo production of inflammatory cytokines by circulating antigen-presenting cells in aging type-2 diabetic men with partial androgen deficiency. Journal of Endocrinology 189 595-604. (https://doi.org/10.1677/joe.1.06779)

Daniels G, Gellert LL, Melamed J, Hatcher D, Li Y, Wei J, Wang J \& Lee P 2014 Decreased expression of stromal estrogen receptor alpha and beta in prostate cancer. American Journal of Translational Research 6 140-146.

De Bosscher K, Vanden Berghe W \& Haegeman G 2006 Cross-talk between nuclear receptors and nuclear factor kappaB. Oncogene 25 6868-6886. (https://doi.org/10.1038/sj.onc.1209935)

De Gendt K \& Verhoeven G 2012 Tissue- and cell-specific functions of the androgen receptor revealed through conditional knockout models in mice. Molecular and Cellular Endocrinology 352 13-25. (https://doi.org/10.1016/j.mce.2011.08.008)

de Oliveira S, Rosowski EE \& Huttenlocher A 2016 Neutrophil migration in infection and wound repair: going forward in reverse. Nature Reviews Immunology 16 378-391. (https://doi.org/10.1038/ nri.2016.49)

Death AK, McGrath KC, Sader MA, Nakhla S, Jessup W, Handelsman DJ \& Celermajer DS 2004 Dihydrotestosterone promotes vascular cell adhesion molecule-1 expression in male human endothelial cells via a nuclear factor-kappaB-dependent pathway. Endocrinology 145 1889-1897. (https://doi.org/10.1210/en.2003-0789)

Dehm SM \& Tindall DJ 2011 Alternatively spliced androgen receptor variants. Endocrine-Related Cancer 18 R183-R196. (https://doi. org/10.1530/ERC-11-0141) 
Dulos J, Carven GJ, van Boxtel SJ, Evers S, Driessen-Engels LJ, Hobo W, Gorecka MA, de Haan AF, Mulders P, Punt CJ, et al. 2012 PD-1 blockade augments Th1 and Th17 and suppresses Th2 responses in peripheral blood from patients with prostate and advanced melanoma cancer. Journal of Immunotherapy 35 169-178. (https://doi. org/10.1097/CJI.0b013e318247a4e7)

Ebelt K, Babaryka G, Frankenberger B, Stief CG, Eisenmenger W, Kirchner T, Schendel DJ \& Noessner E 2009 Prostate cancer lesions are surrounded by FOXP3+, PD-1+ and B7-H1+ lymphocyte clusters. European Journal of Cancer 45 1664-1672. (https://doi.org/10.1016/j. ejca.2009.02.015)

Efstathiou E, Titus M, Tsavachidou D, Tzelepi V, Wen S, Hoang A, Molina A, Chieffo N, Smith LA, Karlou M, et al. 2012 Effects of abiraterone acetate on androgen signaling in castrate-resistant prostate cancer in bone. Journal of Clinical Oncology 30 637-643. (https://doi.org/10.1200/JCO.2010.33.7675)

Eisenberger MA, Blumenstein BA, Crawford ED, Miller G, McLeod DG, Loehrer PJ, Wilding G, Sears K, Culkin DJ, Thompson IM Jr et al. 1998 Bilateral orchiectomy with or without flutamide for metastatic prostate cancer. New England Journal of Medicine 339 1036-1042. (https://doi.org/10.1056/NEJM199810083391504)

Eisermann K, Wang D, Jing Y, Pascal LE \& Wang Z 2013 Androgen receptor gene mutation, rearrangement, polymorphism. Translational Andrology and Urology 2 137-147.

Ellis TM, Moser MT, Le PT, Flanigan RC \& Kwon ED 2001 Alterations in peripheral B cells and B cell progenitors following androgen ablation in mice. International Immunology 13 553-558. (https://doi org/10.1093/intimm/13.4.553)

Elrefaey S, Massaro MA, Chiocca S, Chiesa F \& Ansarin M 2014 HPV in oropharyngeal cancer: the basics to know in clinical practice. Acta Otorhinolaryngologica Italica 34 299-309.

Escamilla J, Schokrpur S, Liu C, Priceman SJ, Moughon D, Jiang Z, Pouliot F, Magyar C, Sung JL, Xu J, et al. 2015 CSF1 receptor targeting in prostate cancer reverses macrophage-mediated resistance to androgen blockade therapy. Cancer Research 75 950-962. (https:// doi.org/10.1158/0008-5472.CAN-14-0992)

Fang LY, Izumi K, Lai KP, Liang L, Li L, Miyamoto H, Lin WJ \& Chang C 2013 Infiltrating macrophages promote prostate tumorigenesis via modulating androgen receptor-mediated CCL4-STAT3 signaling. Cancer Research 73 5633-5646. (https://doi.org/10.1158/0008-5472. CAN-12-3228)

Ferlay J, Soerjomataram I, Dikshit R, Eser S, Mathers C, Rebelo M, Parkin DM, Forman D \& Bray F 2015 Cancer incidence and mortality worldwide: sources, methods and major patterns in GLOBOCAN 2012. International Journal of Cancer 136 E359-E386. (https://doi.org/10.1002/ijc.29210)

Flammiger A, Bayer F, Cirugeda-Kuhnert A, Huland H, Tennstedt P, Simon R, Minner S, Bokemeyer C, Sauter G, Schlomm T, et al. 2012 Intratumoral $\mathrm{T}$ but not $\mathrm{B}$ lymphocytes are related to clinical outcome in prostate cancer. Acta Pathologica, Microbiologica et Immunologica Scandinavica 120 901-908. (https://doi. org/10.1111/j.1600-0463.2012.02924.x)

Foley C \& Mitsiades N 2016 Moving beyond the androgen receptor (AR): targeting AR-interacting proteins to treat prostate cancer. Hormone Cancer 7 84-103. (https://doi.org/10.1007/s12672-0150239-9)

Fridman WH, Zitvogel L, Sautes-Fridman C \& Kroemer G 2017 The immune contexture in cancer prognosis and treatment. Nature Reviews Clinical Oncology 14 717-734. (https://doi.org/10.1038/ nrclinonc.2017.101)

Fujimoto N, Miyamoto H, Mizokami A, Harada S, Nomura M, Ueta Y, Sasaguri T \& Matsumoto T 2007 Prostate cancer cells increase androgen sensitivity by increase in nuclear androgen receptor and androgen receptor coactivators; a possible mechanism of hormoneresistance of prostate cancer cells. Cancer Investigation 25 32-37. (https://doi.org/10.1080/07357900601130698)
Galon J, Pages F, Marincola FM, Thurin M, Trinchieri G, Fox BA, Gajewski TF \& Ascierto PA 2012 The immune score as a new possible approach for the classification of cancer. Journal of Translational Medicine 10 1. (https://doi.org/10.1186/1479-5876-10-1)

Gangkak G, Bhattar R, Mittal A, Yadav SS, Tomar V, Yadav A \& Mehta J 2017 Immunohistochemical analysis of estrogen receptors in prostate and clinical correlation in men with benign prostatic hyperplasia. Investigative and Clinical Urology 58 117-126. (https:// doi.org/10.4111/icu.2017.58.2.117)

Gannon PO, Poisson AO, Delvoye N, Lapointe R, Mes-Masson AM \& Saad F 2009 Characterization of the intra-prostatic immune cell infiltration in androgen-deprived prostate cancer patients. Journal of Immunological Methods 348 9-17. (https://doi.org/10.1016/j. jim.2009.06.004)

Gleave M, Hsieh JT, Gao CA, von Eschenbach AC \& Chung LW 1991 Acceleration of human prostate cancer growth in vivo by factors produced by prostate and bone fibroblasts. Cancer Research $\mathbf{5 1}$ 3753-3761.

Gleave ME, Hsieh JT, von Eschenbach AC \& Chung LW 1992 Prostate and bone fibroblasts induce human prostate cancer growth in vivo: implications for bidirectional tumor-stromal cell interaction in prostate carcinoma growth and metastasis. Journal of Urology 147 1151-1159. (https://doi.org/10.1016/S0022-5347(17)37506-7)

Gomella LG 2009 Effective testosterone suppression for prostate cancer: is there a best castration therapy? Reviews in Urology 11 52-60.

Gomella LG, Singh J, Lallas C \& Trabulsi EJ 2010 Hormone therapy in the management of prostate cancer: evidence-based approaches. Therapeutic Advances in Urology 2 171-181. (https://doi. org/10.1177/1756287210375270)

Gomez F, Ruiz P, Lopez R, Rivera C, Romero S \& Bernal JA 2000 Effects of androgen treatment on expression of macrophage Fcgamma receptors. Clinical and Diagnostic Laboratory Immunology 7 682-686.

Grimm EA, Sikora AG \& Ekmekcioglu S 2013 Molecular pathways: inflammation-associated nitric-oxide production as a cancersupporting redox mechanism and a potential therapeutic target. Clinical Cancer Research 19 5557-5563. (https://doi. org/10.1158/1078-0432.CCR-12-1554)

Grivennikov SI, Greten FR \& Karin M 2010 Immunity, inflammation, and cancer. Cell 140 883-899. (https://doi.org/10.1016/j. cell.2010.01.025)

Gu X, Gao X, Li X, Qi X, Ma M, Qin S, Yu H, Sun S, Zhou D \& Wang W 2016 Prognostic significance of neutrophil-to-lymphocyte ratio in prostate cancer: evidence from 16,266 patients. Scientific Reports 6 22089. (https://doi.org/10.1038/srep22089)

Guo Z, Yang X, Sun F, Jiang R, Linn DE, Chen H, Chen H, Kong X, Melamed J, Tepper CG, et al. 2009 A novel androgen receptor splice variant is up-regulated during prostate cancer progression and promotes androgen depletion-resistant growth. Cancer Research 69 2305-2313. (https://doi.org/10.1158/0008-5472.CAN-08-3795)

Halama N, Zoernig I, Grabe N \& Jaeger D 2012 The local immunological microenvironment in colorectal cancer as a prognostic factor for treatment decisions in the clinic: the way ahead. Oncoimmunology $\mathbf{1}$ 62-66. (https://doi.org/10.4161/onci.1.1.18460)

Heemers HV \& Tindall DJ 2007 Androgen receptor (AR) coregulators: a diversity of functions converging on and regulating the AR transcriptional complex. Endocrine Reviews 28 778-808. (https://doi. org/10.1210/er.2007-0019)

Heinlein CA \& Chang C 2004 Androgen receptor in prostate cancer. Endocrine Reviews 25 276-308. (https://doi.org/10.1210/er.2002-0032)

Henshall SM, Quinn DI, Lee CS, Head DR, Golovsky D, Brenner PC, Delprado W, Stricker PD, Grygiel JJ \& Sutherland RL 2001 Altered expression of androgen receptor in the malignant epithelium and adjacent stroma is associated with early relapse in prostate cancer. Cancer Research 61 423-427.

Herbertz S, Sawyer JS, Stauber AJ, Gueorguieva I, Driscoll KE, Estrem ST, Cleverly AL, Desaiah D, Guba SC, Benhadji KA, et al. 2015 Clinical 
development of galunisertib (LY2157299 monohydrate), a small molecule inhibitor of transforming growth factor-beta signaling pathway. Drug Design, Development and Therapy 9 4479-4499. (https://doi.org/10.2147/DDDT.S86621)

Higano CS, Schellhammer PF, Small EJ, Burch PA, Nemunaitis J, Yuh L, Provost N \& Frohlich MW 2009 Integrated data from 2 randomized, double-blind, placebo-controlled, phase 3 trials of active cellular immunotherapy with sipuleucel-T in advanced prostate cancer. Cancer 115 3670-3679. (https://doi.org/10.1002/cncr.24429)

Hill R, Song Y, Cardiff RD \& Van Dyke T 2005 Selective evolution of stromal mesenchyme with p53 loss in response to epithelial tumorigenesis. Cell 123 1001-1011. (https://doi.org/10.1016/j. cell.2005.09.030)

Hotte SJ \& Saad F 2010 Current management of castrate-resistant prostate cancer. Current Oncology 17 (Supplement 2) S72-S79.

Hu R, Dunn TA, Wei S, Isharwal S, Veltri RW, Humphreys E, Han M, Partin AW, Vessella RL, Isaacs WB, et al. 2009 Ligand-independent androgen receptor variants derived from splicing of cryptic exons signify hormone-refractory prostate cancer. Cancer Research 69 16-22. (https://doi.org/10.1158/0008-5472.CAN-08-2764)

Hu J, Wang G \& Sun T 2017 Dissecting the roles of the androgen receptor in prostate cancer from molecular perspectives. Tumor Biology 39 1010428317692259. (https://doi. org/10.1177/1010428317692259)

Huang CK, Pang H, Wang L, Niu Y, Luo J, Chang E, Sparks JD, Lee SO \& Chang C 2014 New therapy via targeting androgen receptor in monocytes/macrophages to battle atherosclerosis. Hypertension $\mathbf{6 3}$ 1345-1353. (https://doi.org/10.1161/HYPERTENSIONAHA.113.02804)

Hussain M, Fizazi K, Saad F, Shore ND, Heidenreich A, Hirmand M, Perabo F, Khondher Z, Modelska K \& Sternberg CN 2014 PROSPER: a phase 3 study of enzalutamide in nonmetastatic (M0) castrationresistant prostate cancer (CRPC) patients. Journal of Clinical Oncology 32 TPS5094.

Italiani P \& Boraschi D 2014 From monocytes to M1/M2 macrophages: phenotypical vs functional differentiation. Frontiers in Immunology $\mathbf{5}$ 514. (https://doi.org/10.3389/fimmu.2014.00514)

Izumi K \& Chang C 2013 Targeting inflammatory cytokines-androgen receptor (AR) signaling with ASC-J9(R) to better battle prostate cancer progression. Oncoimmunology 2 e26853. (https://doi. org/10.4161/onci.26853)

Izumi K, Fang LY, Mizokami A, Namiki M, Li L, Lin WJ \& Chang C 2013 Targeting the androgen receptor with siRNA promotes prostate cancer metastasis through enhanced macrophage recruitment via CCL2/CCR2-induced STAT3 activation. EMBO Molecular Medicine 5 1383-1401. (https://doi.org/10.1002/emmm.201202367)

Izumi K, Li L \& Chang C 2014 Androgen receptor and immune inflammation in benign prostatic hyperplasia and prostate cancer. Clinical Investigation 4 935-950. (https://doi.org/10.4155/cli.14.77)

Jiang H, Zhang L, Liu J, Chen Z, Na R, Ding G, Zhang H \& Ding Q 2012 Knockdown of zinc finger protein X-linked inhibits prostate cancer cell proliferation and induces apoptosis by activating caspase- 3 and caspase-9. Cancer Gene Therapy 19 684-689. (https://doi.org/10.1038/ cgt.2012.53)

Joyce JA 2005 Therapeutic targeting of the tumor microenvironment. Cancer Cell 7 513-520. (https://doi.org/10.1016/j.ccr.2005.05.024)

Kaarbo M, Klokk TI \& Saatcioglu F 2007 Androgen signaling and its interactions with other signaling pathways in prostate cancer. Bioessays 29 1227-1238. (https://doi.org/10.1002/bies.20676)

Kadota K, Nitadori J, Ujiie H, Buitrago DH, Woo KM, Sima CS, Travis WD, Jones DR \& Adusumilli PS 2015 Prognostic impact of immune microenvironment in lung squamous cell carcinoma: tumor-infiltrating CD10+ Neutrophil/CD20+ Lymphocyte ratio as an independent prognostic factor. Journal of Thoracic Oncology 10 1301-1310. (https://doi.org/10.1097/JTO.0000000000000617)

Kantoff PW, Higano CS, Shore ND, Berger ER, Small EJ, Penson DF, Redfern CH, Ferrari AC, Dreicer R, Sims RB, et al. 2010a Sipuleucel-T immunotherapy for castration-resistant prostate cancer. New England Journal of Medicine 363 411-422. (https://doi.org/10.1056/ NEJMoa1001294)

Kantoff PW, Schuetz TJ, Blumenstein BA, Glode LM, Bilhartz DL, Wyand M, Manson K, Panicali DL, Laus R, Schlom J, et al. $2010 b$ Overall survival analysis of a phase II randomized controlled trial of a Poxviral-based PSA-targeted immunotherapy in metastatic castration-resistant prostate cancer. Journal of Clinical Oncology 28 1099-1105. (https://doi.org/10.1200/JCO.2009.25.0597)

Keil KP, Abler LL, Laporta J, Altmann HM, Yang B, Jarrard DF, Hernandez LL \& Vezina CM 2014 Androgen receptor DNA methylation regulates the timing and androgen sensitivity of mouse prostate ductal development. Developmental Biology 396 237-245. (https://doi.org/10.1016/j.ydbio.2014.10.006)

Kissick HT, Sanda MG, Dunn LK, Pellegrini KL, On ST, Noel JK \& Arredouani MS 2014 Androgens alter T-cell immunity by inhibiting T-helper 1 differentiation. PNAS 111 9887-9892. (https://doi. org/10.1073/pnas.1402468111)

Knutson KL \& Disis ML 2005 Tumor antigen-specific T helper cells in cancer immunity and immunotherapy. Cancer Immunology, Immunotherapy 54 721-728. (https://doi.org/10.1007/s00262-0040653-2)

Ko S, Shi L, Kim S, Song CS \& Chatterjee B 2008 Interplay of nuclear factor-kappaB and B-myb in the negative regulation of androgen receptor expression by tumor necrosis factor alpha. Molecular Endocrinology 22 273-286. (https://doi.org/10.1210/me.2007-0332)

Koivisto P, Kononen J, Palmberg C, Tammela T, Hyytinen E, Isola J, Trapman J, Cleutjens K, Noordzij A, Visakorpi T, et al. 1997 Androgen receptor gene amplification: a possible molecular mechanism for androgen deprivation therapy failure in prostate cancer. Cancer Research 57 314-319.

Koretzky GA 2010 Multiple roles of CD4 and CD8 in T cell activation. Journal of Immunology 185 2643-2644. (https://doi.org/10.4049/ jimmunol.1090076)

Kumar V, Patel S, Tcyganov E \& Gabrilovich DI 2016 The nature of myeloid-derived suppressor cells in the tumor microenvironment. Trends in Immunology 37 208-220. (https://doi.org/10.1016/j. it.2016.01.004)

Kupelian P, Kuban D, Thames H, Levy L, Horwitz E, Martinez A, Michalski J, Pisansky T, Sandler H, Shipley W, et al. 2005 Improved biochemical relapse-free survival with increased external radiation doses in patients with localized prostate cancer: the combined experience of nine institutions in patients treated in 1994 and 1995. International Journal of Radiation Oncology, Biology, Physics 61 415-419. (https://doi.org/10.1016/j.ijrobp.2004.05.018)

Lahita RG 1997 Effects of gender on the immune system. Implications for neuropsychiatric systemic lupus erythematosus. Annals of the New York Academy of Sciences $\mathbf{8 2 3}$ 247-251. (https://doi. org/10.1111/j.1749-6632.1997.tb48396.x)

Lai JJ, Lai KP, Zeng W, Chuang KH, Altuwaijri S \& Chang C 2012a Androgen receptor influences on body defense system via modulation of innate and adaptive immune systems: lessons from conditional AR knockout mice. American Journal of Pathology $\mathbf{1 8 1}$ 1504-1512. (https://doi.org/10.1016/j.ajpath.2012.07.008)

Lai KP, Yamashita S, Huang CK, Yeh S \& Chang C 2012b Loss of stromal androgen receptor leads to suppressed prostate tumourigenesis via modulation of pro-inflammatory cytokines/chemokines. EMBO Molecular Medicine 4 791-807. (https://doi.org/10.1002/ emmm.201101140)

Lai KP, Lai JJ, Chang P, Altuwaijri S, Hsu JW, Chuang KH, Shyr CR, Yeh S \& Chang C 2013 Targeting thymic epithelia AR enhances T-cell reconstitution and bone marrow transplant grafting efficacy. Molecular Endocrinology 27 25-37. (https://doi.org/10.1210/me.20121244)

Lanciotti M, Masieri L, Raspollini MR, Minervini A, Mari A, Comito G, Giannoni E, Carini M, Chiarugi P \& Serni S 2014 The role of M1 and 
M2 macrophages in prostate cancer in relation to extracapsular tumor extension and biochemical recurrence after radical prostatectomy. BioMed Research International 2014 486798. (https:// doi.org/10.1155/2014/486798)

Leach DA \& Buchanan G 2017 Stromal androgen receptor in prostate cancer development and progression. Cancers 9 E10. (https://doi. $\operatorname{org} / 10.3390 /$ cancers9010010)

Leach DA, Need EF, Toivanen R, Trotta AP, Palethorpe HM, Tamblyn DJ, Kopsaftis T, England GM, Smith E, Drew PA, et al. 2015 Stromal androgen receptor regulates the composition of the microenvironment to influence prostate cancer outcome. Oncotarget 6 16135-16150.

Leach DA, Panagopoulos V, Nash C, Bevan C, Thomson AA, Selth LA \& Buchanan G 2017 Cell-lineage specificity and role of AP-1 in the prostate fibroblast androgen receptor cistrome. Molecular and Cellular Endocrinology 439 261-272. (https://doi.org/10.1016/j. mce.2016.09.010)

Leav I, Lau KM, Adams JY, McNeal JE, Taplin ME, Wang J, Singh H \& Ho SM 2001 Comparative studies of the estrogen receptors beta and alpha and the androgen receptor in normal human prostate glands, dysplasia, and in primary and metastatic carcinoma. American Journal of Pathology 159 79-92. (https://doi.org/10.1016/S00029440(10)61676-8)

Leitzmann MF \& Rohrmann S 2012 Risk factors for the onset of prostatic cancer: age, location, and behavioral correlates. Clinical Epidemiology 4 1-11. (https://doi.org/10.2147/CLEP.S16747)

Lessard L, Labbe DP, Deblois G, Begin LR, Hardy S, Mes-Masson AM, Saad F, Trotman LC, Giguere V \& Tremblay ML 2012 PTP1B is an androgen receptor-regulated phosphatase that promotes the progression of prostate cancer. Cancer Research 72 1529-1537. (https://doi.org/10.1158/0008-5472.CAN-11-2602)

Li Y, Li CX, Ye H, Chen F, Melamed J, Peng Y, Liu J, Wang Z, Tsou HC, Wei J, et al. 2008 Decrease in stromal androgen receptor associates with androgen-independent disease and promotes prostate cancer cell proliferation and invasion. Journal of Cellular and Molecular Medicine 12 2790-2798. (https://doi. org/10.1111/j.1582-4934.2008.00279.x)

Liao CP, Chen LY, Luethy A, Kim Y, Kani K, MacLeod AR \& Gross ME 2017 Androgen receptor in cancer-associated fibroblasts influences stemness in cancer cells. Endocrine-Related Cancer 24 157-170. (https://doi.org/10.1530/ERC-16-0138)

Lin KT \& Wang LH 2016 New dimension of glucocorticoids in cancer treatment. Steroids 111 84-88. (https://doi.org/10.1016/j. steroids.2016.02.019)

Ling S, Dai A, Williams MR, Myles K, Dilley RJ, Komesaroff PA \& Sudhir K 2002 Testosterone (T) enhances apoptosis-related damage in human vascular endothelial cells. Endocrinology 143 1119-1125. (https://doi.org/10.1210/endo.143.3.8679)

Liu PY, Death AK \& Handelsman DJ 2003 Androgens and cardiovascular disease. Endocrine Reviews 24 313-340. (https://doi.org/10.1210/ er.2003-0005)

Liu C, Ueno T, Kuse S, Saito F, Nitta T, Piali L, Nakano H, Kakiuchi T, Lipp M, Hollander GA, et al. 2005 The role of CCL21 in recruitment of T-precursor cells to fetal thymi. Blood 105 31-39. (https://doi. org/10.1182/blood-2004-04-1369)

Liva SM \& Voskuhl RR 2001 Testosterone acts directly on CD4+ T lymphocytes to increase IL-10 production. Journal of Immunology 167 2060-2067. (https://doi.org/10.4049/jimmunol.167.4.2060)

Locke JA, Guns ES, Lubik AA, Adomat HH, Hendy SC, Wood CA, Ettinger SL, Gleave ME \& Nelson CC 2008 Androgen levels increase by intratumoral de novo steroidogenesis during progression of castration-resistant prostate cancer. Cancer Research 68 6407-6415. (https://doi.org/10.1158/0008-5472.CAN07-5997)

Madan RA, Gulley JL, Schlom J, Steinberg SM, Liewehr DJ, Dahut WL \& Arlen PM 2008 Analysis of overall survival in patients with nonmetastatic castration-resistant prostate cancer treated with vaccine, nilutamide, and combination therapy. Clinical Cancer Research 14 4526-4531. (https://doi.org/10.1158/1078-0432.CCR07-5048)

Mantalaris A, Panoskaltsis N, Sakai Y, Bourne P, Chang C, Messing EM \& Wu JH 2001 Localization of androgen receptor expression in human bone marrow. Journal of Pathology 193 361-366. (https://doi. org/10.1002/1096-9896(0000)9999:9999<::AIDPATH803>3.0.CO;2-W)

Marcelli M, Ittmann M, Mariani S, Sutherland R, Nigam R, Murthy L, Zhao Y, Di DConcini, Puxeddu E, Esen A, et al. 2000 Androgen receptor mutations in prostate cancer. Cancer Research 60 944-949.

McLeod DG 2005 The effective management of biochemical recurrence in patients with prostate cancer. Reviews in Urology 7 (Supplement 5) S29-S36.

Mercader M, Bodner BK, Moser MT, Kwon PS, Park ES, Manecke RG, Ellis TM, Wojcik EM, Yang D, Flanigan RC, et al. 2001 T cell infiltration of the prostate induced by androgen withdrawal in patients with prostate cancer. PNAS 98 14565-14570. (https://doi. org/10.1073/pnas.251140998)

Messingham KA, Shirazi M, Duffner LA, Emanuele MA \& Kovacs EJ 2001 Testosterone receptor blockade restores cellular immunity in male mice after burn injury. Journal of Endocrinology 169 299-308. (https:// doi.org/10.1677/joe.0.1690299)

Miller L \& Hunt JS 1996 Sex steroid hormones and macrophage function. Life Science 59 1-14. (https://doi.org/10.1016/00243205(96)00122-1)

Miller AM, Lundberg K, Ozenci V, Banham AH, Hellstrom M, Egevad L \& Pisa P 2006 CD4+CD25high T cells are enriched in the tumor and peripheral blood of prostate cancer patients. Journal of Immunology 177 7398-7405. (https://doi.org/10.4049/jimmunol.177.10.7398)

Mohler JL, Chen Y, Hamil K, Hall SH, Cidlowski JA, Wilson EM, French FS \& Sar M 1996 Androgen and glucocorticoid receptors in the stroma and epithelium of prostatic hyperplasia and carcinoma. Clinical Cancer Research 2 889-895.

Mottet N, Bellmunt J, Bolla M, Briers E, Cumberbatch MG, De Santis M, Fossati N, Gross T, Henry AM, Joniau S, et al. 2017 EAU-ESTRO-SIOG Guidelines on Prostate Cancer. Part 1: screening, diagnosis, and local treatment with curative intent. European Urology 71 618-629. (https://doi.org/10.1016/j.eururo.2016.08.003)

Mueller MM \& Fusenig NE 2004 Friends or foes - bipolar effects of the tumour stroma in cancer. Nature Reviews Cancer 4 839-849. (https:// doi.org/10.1038/nrc1477)

Nakajima Y, DelliPizzi AM, Mallouh C \& Ferreri NR 1996 TNF-mediated cytotoxicity and resistance in human prostate cancer cell lines. Prostate 29 296-302. (https://doi.org/10.1002/(SICI)10970045(199611)29:5<296::AID-PROS4>3.0.CO;2-8)

Nash C, Boufaied N, Mills IG, Franco OE, Hayward SW \& Thomson AA 2017 Genome-wide analysis of AR binding and comparison with transcript expression in primary human fetal prostate fibroblasts and cancer associated fibroblasts. Molecular and Cellular Endocrinology [epub]. (https://doi.org/10.1016/j. mce.2017.05.006)

New York State Department of Environmental Conservation 2009 Guidelines for Conducting Bird and Bat Studies at Commercial Wind Energy Projects. Albany, NY: Division of Fish Wildlife and Marine Resources.

Nimmerjahn F \& Ravetch JV 2008 Fcgamma receptors as regulators of immune responses. Nature Reviews Immunology 8 34-47. (https://doi. org/10.1038/nri2206)

Niu Y, Altuwaijri S, Lai KP, Wu CT, Ricke WA, Messing EM, Yao J, Yeh S \& Chang C 2008a Androgen receptor is a tumor suppressor and proliferator in prostate cancer. PNAS 105 12182-12187. (https://doi. org/10.1073/pnas.0804700105)

Niu Y, Altuwaijri S, Yeh S, Lai KP, Yu S, Chuang KH, Huang SP, Lardy H \& Chang C 2008b Targeting the stromal androgen receptor in 
primary prostate tumors at earlier stages. PNAS 105 12188-12193. (https://doi.org/10.1073/pnas.0804701105)

Nonomura N, Takayama H, Nakayama M, Nakai Y, Kawashima A, Mukai M, Nagahara A, Aozasa K \& Tsujimura A 2011 Infiltration of tumour-associated macrophages in prostate biopsy specimens is predictive of disease progression after hormonal therapy for prostate cancer. BJU International 107 1918-1922. (https://doi. org/10.1111/j.1464-410X.2010.09804.x)

O'Hara L \& Smith LB 2016 Development and characterization of cellspecific androgen receptor knockout mice. Methods in Molecular Biology 1443 219-248. (https://doi.org/10.1007/978-1-4939-37240_14)

Olumi AF, Grossfeld GD, Hayward SW, Carroll PR, Tlsty TD \& Cunha GR 1999 Carcinoma-associated fibroblasts direct tumor progression of initiated human prostatic epithelium. Cancer Research 59 5002-5011.

Paland N, Kamer I, Kogan-Sakin I, Madar S, Goldfinger N \& Rotter V 2009 Differential influence of normal and cancer-associated fibroblasts on the growth of human epithelial cells in an in vitro cocultivation model of prostate cancer. Molecular Cancer Research 7 1212-1223. (https://doi.org/10.1158/1541-7786.MCR-09-0073)

Peeters ST, Heemsbergen WD, Koper PC, van Putten WL, Slot A, Dielwart MF, Bonfrer JM, Incrocci L \& Lebesque JV 2006 Doseresponse in radiotherapy for localized prostate cancer: results of the Dutch multicenter randomized phase III trial comparing 68 Gy of radiotherapy with 78 Gy. Journal of Clinical Oncology 24 1990-1996. (https://doi.org/10.1200/JCO.2005.05.2530)

Pu Y, Xu M, Liang Y, Yang K, Guo Y, Yang X \& Fu YX 2016 Androgen receptor antagonists compromise $\mathrm{T}$ cell response against prostate cancer leading to early tumor relapse. Science Translational Medicine $\mathbf{8}$ 333ra347. (https://doi.org/10.1126/scitranslmed.aad5659)

Rathkopf D \& Scher HI 2013 Androgen receptor antagonists in castration-resistant prostate cancer. Cancer Journal 19 43-49. (https:// doi.org/10.1097/PPO.0b013e318282635a)

Rettew JA, Huet-Hudson YM \& Marriott I 2008 Testosterone reduces macrophage expression in the mouse of toll-like receptor 4, a trigger for inflammation and innate immunity. Biology of Reproduction $\mathbf{7 8}$ 432-437. (https://doi.org/10.1095/biolreprod.107.063545)

Ricke EA, Williams K, Lee YF, Couto S, Wang Y, Hayward SW, Cunha GR \& Ricke WA 2012 Androgen hormone action in prostatic carcinogenesis: stromal androgen receptors mediate prostate cancer progression, malignant transformation and metastasis. Carcinogenesis 33 1391-1398. (https://doi.org/10.1093/carcin/bgs153)

Roden AC, Moser MT, Tri SD, Mercader M, Kuntz SM, Dong H, Hurwitz AA, McKean DJ, Celis E, Leibovich BC, et al. 2004 Augmentation of $\mathrm{T}$ cell levels and responses induced by androgen deprivation. Journal of Immunology 173 6098-6108. (https://doi. org/10.4049/jimmunol.173.10.6098)

Romagnani S 1999 Th1/Th2 cells. Inflammatory Bowel Diseases 5 285-294. (https://doi.org/10.1097/00054725-199911000-00009)

Rowley DR 1998 What might a stromal response mean to prostate cancer progression? Cancer and Metastasis Reviews 17 411-419.

Royuela M, de Miguel MP, Bethencourt FR, Sanchez-Chapado M, Fraile B, Arenas MI and Paniagua R 2001 Estrogen receptors alpha and beta in the normal, hyperplastic and carcinomatous human prostate. Journal of Endocrinology 168 447-454. (https://doi. org/10.1677/joe.0.1680447)

Schaufele F, Carbonell X, Guerbadot M, Borngraeber S, Chapman MS, Ma AA, Miner JN \& Diamond MI 2005 The structural basis of androgen receptor activation: intramolecular and intermolecular amino-carboxy interactions. PNAS 102 9802-9807. (https://doi. org/10.1073/pnas.0408819102)

Scher HI, Lu D, Schreiber NA, Louw J, Graf RP, Vargas HA, Johnson A, Jendrisak A, Bambury R, Danila D, et al. 2016 Association of AR-V7 on circulating tumor cells as a treatment-specific biomarker with outcomes and survival in castration-resistant prostate cancer. JAMA
Oncology 2 1441-1449. (https://doi.org/10.1001/ jamaoncol.2016.1828)

Schuurs AH \& Verheul HA 1990 Effects of gender and sex steroids on the immune response. Journal of Steroid Biochemistry 35 157-172. (https://doi.org/10.1016/0022-4731(90)90270-3)

Sempowski GD, Hale LP, Sundy JS, Massey JM, Koup RA, Douek DC, Patel DD \& Haynes BF 2000 Leukemia inhibitory factor, oncostatin M, IL-6, and stem cell factor mRNA expression in human thymus increases with age and is associated with thymic atrophy. Journal of Immunology 164 2180-2187. (https://doi.org/10.4049/ jimmunol.164.4.2180)

Sfanos KS, Bruno TC, Maris CH, Xu L, Thoburn CJ, DeMarzo AM, Meeker AK, Isaacs WB \& Drake CG 2008 Phenotypic analysis of prostate-infiltrating lymphocytes reveals TH17 and Treg skewing. Clinical Cancer Research 14 3254-3261. (https://doi. org/10.1158/1078-0432.CCR-07-5164)

Singh M, Daniels G, Li Y \& Lee P 2013 Expression and function of stromal androgen receptor in prostate cancer. In Advances in Prostate Cancer, chapter 19. Ed G Hamilton. London, UK: IntechOpen. (https://doi.org/10.5772/52425)

Singh M, Jha R, Melamed J, Shapiro E, Hayward SW \& Lee P 2014 Stromal androgen receptor in prostate development and cancer. American Journal of Pathology 184 2598-2607. (https://doi. org/10.1016/j.ajpath.2014.06.022)

Slavin S, Yeh CR, Da J, Yu S, Miyamoto H, Messing EM, Guancial E \& Yeh S 2014 Estrogen receptor alpha in cancer-associated fibroblasts suppresses prostate cancer invasion via modulation of thrombospondin 2 and matrix metalloproteinase 3. Carcinogenesis $\mathbf{3 5}$ 1301-1309. (https://doi.org/10.1093/carcin/bgt488)

Smithson G, Couse JF, Lubahn DB, Korach KS \& Kincade PW 1998 The role of estrogen receptors and androgen receptors in sex steroid regulation of B lymphopoiesis. Journal of Immunology 161 27-34.

Spary LK, Salimu J, Webber JP, Clayton A, Mason MD \& Tabi Z 2014 Tumor stroma-derived factors skew monocyte to dendritic cell differentiation toward a suppressive CD14+ PD-L1+ phenotype in prostate cancer. Oncoimmunology 3 e955331. (https://doi.org/10.4161 /21624011.2014.955331)

Steinkamp MP, O'Mahony OA, Brogley M, Rehman H, Lapensee EW, Dhanasekaran S, Hofer MD, Kuefer R, Chinnaiyan A, Rubin MA, et al. 2009 Treatment-dependent androgen receptor mutations in prostate cancer exploit multiple mechanisms to evade therapy. Cancer Research 69 4434-4442. (https://doi.org/10.1158/0008-5472. CAN-08-3605)

Stelloo S, Nevedomskaya E, Kim Y, Hoekman L, Bleijerveld OB, Mirza T, Wessels LFA, van Weerden WM, Altelaar AFM, Bergman AM, et al. 2018 Endogenous androgen receptor proteomic profiling reveals genomic subcomplex involved in prostate tumorigenesis. Oncogene 37 313-322. (https://doi.org/10.1038/onc.2017.330)

Supakar PC, Jung MH, Song CS, Chatterjee B \& Roy AK 1995 Nuclear factor kappa B functions as a negative regulator for the rat androgen receptor gene and NF-kappa B activity increases during the agedependent desensitization of the liver. Journal of Biological Chemistry 270 837-842. (https://doi.org/10.1074/jbc.270.2.837)

Tan MH, Li J, Xu HE, Melcher K \& Yong EL 2015 Androgen receptor: structure, role in prostate cancer and drug discovery. Acta Pharmacologica Sinica 36 3-23. (https://doi.org/10.1038/ aps.2014.18)

Tanner MJ, Welliver RC Jr, Chen M, Shtutman M, Godoy A, Smith G, Mian BM \& Buttyan R 2011 Effects of androgen receptor and androgen on gene expression in prostate stromal fibroblasts and paracrine signaling to prostate cancer cells. PLOS ONE 6 e16027. (https://doi.org/10.1371/journal.pone.0016027)

Taplin ME, Bubley GJ, Shuster TD, Frantz ME, Spooner AE, Ogata GK, Keer HN \& Balk SP 1995 Mutation of the androgen-receptor gene in metastatic androgen-independent prostate cancer. New England
() 2018 Society for Endocrinology Published by Bioscientifica Ltd. Printed in Great Britain 
Journal of Medicine 332 1393-1398. (https://doi.org/10.1056/ NEJM199505253322101)

Templeton AJ, McNamara MG, Seruga B, Vera-Badillo FE, Aneja P, Ocana A, Leibowitz-Amit R, Sonpavde G, Knox JJ, Tran B, et al. 2014 Prognostic role of neutrophil-to-lymphocyte ratio in solid tumors: a systematic review and meta-analysis. Journal of the National Cancer Institute 106 dju124. (https://doi.org/10.1093/jnci/dju124)

Topalian SL, Hodi FS, Brahmer JR, Gettinger SN, Smith DC, McDermott DF, Powderly JD, Carvajal RD, Sosman JA, Atkins MB, et al. 2012 Safety, activity, and immune correlates of anti-PD-1 antibody in cancer. New England Journal of Medicine 366 2443-2454. (https://doi.org/10.1056/NEJMoa1200690)

Torre LA, Bray F, Siegel RL, Ferlay J, Lortet-Tieulent J \& Jemal A 2015 Global cancer statistics, 2012. CA: A Cancer Journal for Clinicians 65 87-108. (https://doi.org/10.3322/caac.21262)

Tricoli JV \& Bracken RB 1993 ZFY gene expression and retention in human prostate adenocarcinoma. Genes, Chromosomes and Cancer 6 65-72. (https://doi.org/10.1002/gcc.2870060202)

Uhlman MA, Moul JW, Tang P, Stackhouse DA \& Sun L 2009 Risk stratification in the hormonal treatment of patients with prostate cancer. Therapeutic Advances in Medical Oncology 1 79-94. (https://doi. org/10.1177/1758834009340164)

Vacchio MS, Williams JA \& Hodes RJ 2005 A novel role for CD28 in thymic selection: elimination of $\mathrm{CD} 28 / \mathrm{B} 7$ interactions increases positive selection. European Journal of Immunology 35 418-427. (https://doi.org/10.1002/eji.200424918)

Valdman A, Jaraj SJ, Comperat E, Charlotte F, Roupret M, Pisa P \& Egevad L 2010 Distribution of Foxp3-, CD4- and CD8-positive lymphocytic cells in benign and malignant prostate tissue. Acta Pathologica, Microbiologica et Immunologica Scandinavica 118 360-365. (https://doi.org/10.1111/j.1600-0463.2010.02604.x)

van de Wetering M, Francies HE, Francis JM, Bounova G, Iorio F, Pronk A, van Houdt W, van Gorp J, Taylor-Weiner A, Kester L, et al. 2015 Prospective derivation of a living organoid biobank of colorectal cancer patients. Cell 161 933-945. (https://doi. org/10.1016/j.cell.2015.03.053)

van Royen ME, van Cappellen WA, de Vos C, Houtsmuller AB \& Trapman J 2012 Stepwise androgen receptor dimerization. Journal of Cell Science 125 1970-1979. (https://doi.org/10.1242/jcs.096792)

Vasu C, Wang A, Gorla SR, Kaithamana S, Prabhakar BS \& Holterman MJ 2003 CD80 and CD86 C domains play an important role in receptor binding and co-stimulatory properties. International Immunology $\mathbf{1 5}$ 167-175. (https://doi.org/10.1093/intimm/dxg017)

Vignozzi L, Cellai I, Santi R, Lombardelli L, Morelli A, Comeglio P, Filippi S, Logiodice F, Carini M, Nesi G, et al. 2012 Antiinflammatory effect of androgen receptor activation in human benign prostatic hyperplasia cells. Journal of Endocrinology 214 31-43. (https://doi. org/10.1530/JOE-12-0142)

Visakorpi T, Hyytinen E, Koivisto P, Tanner M, Keinanen R, Palmberg C, Palotie A, Tammela T, Isola J \& Kallioniemi OP 1995 In vivo amplification of the androgen receptor gene and progression of human prostate cancer. Nature Genetics 9 401-406. (https://doi. org/10.1038/ng0495-401)
Viselli SM, Olsen NJ, Shults K, Steizer G \& Kovacs WJ 1995 Immunochemical and flow cytometric analysis of androgen receptor expression in thymocytes. Molecular and Cellular Endocrinology 109 19-26. (https://doi.org/10.1016/0303-7207(95)03479-Q)

Vuk-Pavlovic S, Bulur PA, Lin Y, Qin R, Szumlanski CL, Zhao X \& Dietz AB 2010 Immunosuppressive CD14+HLA-DRlow/- monocytes in prostate cancer. Prostate 70 443-455. (https://doi.org/10.1002/ pros.21078)

Wang Y, Sudilovsky D, Zhang B, Haughney PC, Rosen MA, Wu DS, Cunha TJ, Dahiya R, Cunha GR \& Hayward SW 2001 A human prostatic epithelial model of hormonal carcinogenesis. Cancer Research 61 6064-6072.

Whitacre CC, Reingold SC \& O'Looney PA 1999 A gender gap in autoimmunity. Science 283 1277-1278. (https://doi.org/10.1126/ science.283.5406.1277)

Wikstrom P, Marusic J, Stattin P \& Bergh A 2009 Low stroma androgen receptor level in normal and tumor prostate tissue is related to poor outcome in prostate cancer patients. Prostate 69 799-809. (https:// doi.org/10.1002/pros.20927)

Wunderlich F, Benten WP, Lieberherr M, Guo Z, Stamm O, Wrehlke C, Sekeris CE \& Mossmann H 2002 Testosterone signaling in T cells and macrophages. Steroids 67 535-538. (https://doi.org/10.1016/S0039128X(01)00175-1)

Yu J, Akishita M, Eto M, Ogawa S, Son BK, Kato S, Ouchi Y \& Okabe T 2010 Androgen receptor-dependent activation of endothelial nitric oxide synthase in vascular endothelial cells: role of phosphatidylinositol 3-kinase/akt pathway. Endocrinology 151 1822-1828. (https://doi.org/10.1210/en.2009-1048)

Yu S, Xia S, Yang D, Wang K, Yeh S, Gao Z \& Chang C $2013 a$ Androgen receptor in human prostate cancer-associated fibroblasts promotes prostate cancer epithelial cell growth and invasion. Medical Oncology 30 674. (https://doi.org/10.1007/s12032-0130674-9)

Yu Y, Liu L, Xie N, Xue H, Fazli L, Buttyan R, Wang Y, Gleave M \& Dong X 2013b Expression and function of the progesterone receptor in human prostate stroma provide novel insights to cell proliferation control. Journal of Clinical Endocrinology and Metabolism 98 2887-2896. (https://doi.org/10.1210/jc.2012-4000)

Yu Y, Lee JS, Xie N, Li E, Hurtado-Coll A, Fazli L, Cox M, Plymate S, Gleave M \& Dong X 2014 Prostate stromal cells express the progesterone receptor to control cancer cell mobility. PLOS ONE 9 e92714. (https://doi.org/10.1371/journal.pone.0092714)

Zhang W \& Huang P 2011 Cancer-stromal interactions: role in cell survival, metabolism and drug sensitivity. Cancer Biology and Therapy 11 150-156. (https://doi.org/10.4161/cbt.11.2.14623)

Zhao Y, Tindall DJ \& Huang H 2014 Modulation of androgen receptor by FOXA1 and FOXO1 factors in prostate cancer. International Journal of Biological Sciences 10 614-619. (https://doi.org/10.7150/ ijbs.8389)

Zhao JC, Fong KW, Jin HJ, Yang YA, Kim J \& Yu J 2016 FOXA1 acts upstream of GATA2 and AR in hormonal regulation of gene expression. Oncogene 35 4335-4344. (https://doi.org/10.1038/ onc.2015.496)

Received in final form 26 March 2018

Accepted 4 April 2018

Accepted Preprint published online 4 April 2018 http://erc.endocrinology-journals.org https://doi.org/10.1530/ERC-18-0042
(C) 2018 Society for Endocrinology Published by Bioscientifica Ltd. Printed in Great Britain 